Article

\title{
The Role of the Primary Cilium in Sensing Extracellular pH
}

\author{
Kimberly F. Atkinson ${ }^{1,+}$, Rinzhin T. Sherpa ${ }^{1,+}$ and Surya M. Nauli ${ }^{1,2, *}$ \\ 1 Department of Biomedical \& Pharmaceutical Sciences, Chapman University, Irvine, CA 92618, USA \\ 2 Department of Medicine, Division of Nephrology, University of California Irvine, Irvine, CA 92697, USA \\ * Correspondence: nauli@chapman.edu or snauli@uci.edu; Tel.: +1-714-516-5480 \\ + These authors contributed equally to the work.
}

Received: 14 May 2019; Accepted: 9 July 2019; Published: 11 July 2019

\begin{abstract}
Biosensors on the membrane of the vascular endothelium are responsible for sensing mechanical and chemical signals in the blood. Transduction of these stimuli into intracellular signaling cascades regulate cellular processes including ion transport, gene expression, cell proliferation, and/or cell death. The primary cilium is a well-known biosensor of shear stress but its role in sensing extracellular $\mathrm{pH}$ change has never been examined. As a cellular extension into the immediate microenvironment, the cilium could be a prospective sensor for changes in $\mathrm{pH}$ and regulator of acid response in cells. We aim to test our hypothesis that the primary cilium plays the role of an acid sensor in cells using vascular endothelial and embryonic fibroblast cells as in vitro models. We measure changes in cellular $\mathrm{pH}$ using $\mathrm{pH}$-sensitive 2', $7^{\prime}$-biscarboxyethy1-5,6-carboxyfluorescein acetoxy-methylester (BCECF) fluorescence and mitogen-activated protein kinase (MAPK) activity to quantify responses to both extracellular $\mathrm{pH}\left(\mathrm{pH}_{\mathrm{o}}\right)$ and intracellular $\mathrm{pH}\left(\mathrm{pH}_{\mathrm{i}}\right)$ changes. Our studies show that changes in $\mathrm{pH}_{\mathrm{o}}$ affect $\mathrm{pH}_{\mathrm{i}}$ in both wild-type and cilia-less $\mathrm{Tg} 737$ cells and that the kinetics of the $\mathrm{pH}_{\mathrm{i}}$ response are similar in both cells. Acidic $\mathrm{pH}_{\mathrm{o}}$ or $\mathrm{pH}_{\mathrm{i}}$ was observed to change the length of primary cilia in wild-type cells while the cilia in $\mathrm{Tg} 737$ remained absent. Vascular endothelial cells respond to acidic $\mathrm{pH}$ through activation of ERK1/2 and p38-mediated signaling pathways. The cilia-less $T g 737$ cells exhibit delayed responsiveness to $\mathrm{pH}_{\mathrm{o}}$ dependent and independent $\mathrm{pH}_{\mathrm{i}}$ acidification as depicted in the phosphorylation profile of ERK1/2 and p38. Otherwise, intracellular $\mathrm{pH}$ homeostatic response to acidic $\mathrm{pH}_{\mathrm{o}}$ is similar between wild-type and $\mathrm{Tg} 737$ cells, indicating that the primary cilia may not be the sole sensor for physiological $\mathrm{pH}$ changes. These endothelial cells respond to $\mathrm{pH}$ changes with a predominantly $\mathrm{K}^{+}$-dependent $\mathrm{pH}_{\mathrm{i}}$ recovery mechanism, regardless of ciliary presence or absence.
\end{abstract}

Keywords: acidosis; ERK1/2; p38; pH; primary cilia

\section{Introduction}

The normal blood $\mathrm{pH}$ level is tightly maintained between 7.35 and 7.45 by the renal and respiratory systems along with buffering mediators in the blood. Lowering of blood $\mathrm{pH}<7.35$ or acidosis causes several symptoms such as drowsiness, exhaustion, and arrhythmia depending on the type of acidosis. More dramatic changes in $\mathrm{pH}$ will induce cytotoxicity and neuronal cell death. The vascular endothelium, which also regulates physical dynamics of blood such as local blood flow and pressure, is best suited to measure local circulating blood $\mathrm{pH}$. Any $\mathrm{pH}$ sensor in the body needs to be responsive to extracellular $\mathrm{pH}$ fluctuations and regulate downstream mechanisms for homeostatic adaptation. Such adaptation mechanisms include local activation of ion transporters and modulation of channel activity to balance the intracellular ionic gradient, while global regulation is achieved by adjusting the ventilation or renal excretion. 
Several studies have shown that mitogen-activated protein kinases (MAPKs) are activated by changes in $\mathrm{pH}[1,2]$. The three known MAPKs, extracellular signal-regulated kinase (ERK1/2 aka p32/p44), p38, and JNK1/2, respond to a variety of environmental stimuli to mediate gene expression, ion transport, cell proliferation, and/or apoptosis [3]. ERK1/2 phosphorylation regulates acid-stimulated vacuolar $\mathrm{H}^{+}$-ATPase and $\mathrm{Na}^{+} / \mathrm{H}^{+}$exchanger (NHE) activation [1,4]. When intracellular $\mathrm{pH}$ becomes acidic, ERK1/2 activation acts in parallel with Pyk2 kinase to increase NHE3 activity [5,6]. The MAPK, p38 is activated by various extracellular stress stimuli such as UV light, heat, inflammatory cytokines, and $\mathrm{pH}$ changes. Depending on the initial stimuli, substrates of activated p38 include transcription factors and the MAP kinase-activated protein kinase 2 (MK2). MK2 subsequently activates various small heat shock protein 27 (HSP27), lymphocyte-specific protein 1 (LSP1), cAMP response element-binding protein (CREB) among others $[7,8]$.

In the present study, we explore if the primary cilia, distinct from motile cilia in the brain ventricles or Hensen's node, have a role in acid pH sensation in endothelial cells. Our interest arises from the fact that the primary cilium, a solitary extension of the cell, has been implicated in the sensation of mechanical forces and chemical cues [9-12]. With the localization of various ion channels, G protein-coupled receptors and receptor-cytoskeletal proteins in the ciliary membrane, the primary cilium is a candidate biosensor that responds to a variety of stimuli [13]. Numerous studies have shown that cilia regulate cytosolic calcium influx and intracellular calcium release upon application of shear stress [12,14-16]. The response to blood flow-induced shear stress is very important in the regulation of blood pressure, vascular tone, and vasodilation [13]. As a cellular structure that protrudes out to the vascular lumen and remains in contact with the extracellular milieu, the cilia are poised to be a sensory extension. A recent study on Zebrafish showed localization of acid-sensing ion channels (ASICs), which are proton-gated cation channels, in the cilia of the non-sensory olfactory cell [17]. ASICs are $\mathrm{Na}^{+}$channels activated by external protons and exhibit a rapid response to reduction in extracellular $\mathrm{pH}\left(\mathrm{pH}_{\mathrm{o}}\right)$ below $\mathrm{pH} 6.9$ [18]. Another $\mathrm{Na}^{+}$channel, the alpha-epithelial sodium channel, has been immunodetected in the cilia and are regulated by flow as well as acidic $\mathrm{pH}_{\mathrm{o}}$ through $\mathrm{Na}^{+}$gating phenomenon of self-inhibition [19-21].

A study by Banizs et al. on cilia-less $T g 737$ mice shows that $T g 737$ mice have lower intrinsic buffering power when challenged with a weak acid $\mathrm{NH}_{4}{ }^{+}$compared to wild-type mice [22]. This indicates that primary cilia might be involved in either sensing $\mathrm{pH}_{\mathrm{o}}$ change or regulating intracellular $\mathrm{pH}\left(\mathrm{pH}_{\mathrm{i}}\right)$ in response to $\mathrm{pH}_{\mathrm{o}}$ changes through ciliary ion transport activity. With the evidence that $\mathrm{pH}$ sensitive channels are selectively localized in the cilia of the non-sensory olfactory epithelium [17] and the cilium is known as a sensory organelle of the extracellular milieu $[9,12,23,24]$, we hypothesize that primary cilia could function as $\mathrm{pH}$ sensors. We, therefore, examine the role of the primary cilia in acid-activation of MAPK signaling pathways in endothelial cells. We compare the acid response of cilia-less Tg737 endothelial cells to their wild-type counterparts to examine a possible $\mathrm{pH}$ sensing role of the primary cilia.

\section{Materials and Methods}

\subsection{Cell Culture}

Previously isolated and characterized vascular endothelial cells $\left(\mathrm{Tg} 737^{+/+}\right.$and $\left.\mathrm{Tg} 737^{-/-}\right)$were used for the study $[23,25]$. These cell lines were generated from the same littermates of $T g 737^{+/-}$ mice with Balb/C background. The Tg737 gene encodes for polaris, a structural protein for cilia [26]. These endothelial cells were also immortalized from mice carrying the simian virus-40 (SV40) gene. The promoter of SV40 is regulated by temperature and IFN- $\gamma$. As such, cells were grown under permissive conditions in the presence of $0.75 \mu \mathrm{g} / \mathrm{L} \mathrm{IFN}-\gamma$ at $33^{\circ} \mathrm{C}$ express SV40 large $\mathrm{T}$ antigen regardless of the status of their confluence. The permissive conditions allow cells to hyper-proliferate. When switched to non-permissive conditions in the absence of IFN- $\gamma$ at $37^{\circ} \mathrm{C}$, the endothelial cells completely shut down the SV40 gene. Cells under the non-permissive conditions are readily differentiated $[23,25]$. 
These cells express common markers for endothelial cells, including eNOS, ICAM-2 (CD102), PECAM-1 (CD31), VE-cadherin (CD144), readily responding to acetylcholine, forming endothelial barrier integrity and having functional intracellular calcium signaling, focal adhesion kinase, calmodulin, Akt/PKB, protein kinase $C$ and eNOS activity $[23,25,27]$. Aside from abnormal mechanosensory function due to lacking primary cilia, the $T g 737$ cilia-less cells also have abnormal cell division [28,29].

Three days prior to experiments, cells were cultured under sterile conditions and maintained at $37^{\circ} \mathrm{C}$ in a $5 \% \mathrm{CO}_{2}$ incubator. Cells were kept in Dulbecco's Modification of Eagle's Medium (DMEM), media with $4.5 \mathrm{~g} / \mathrm{L}$ glucose, L-glutamate, and sodium pyruvate (Corning Cellgro) containing $2 \%$ fetal bovine serum (FBS) and 5\% penicillin/streptomycin. DMEM with $2 \%$ FBS is a low serum condition that promotes ciliation [30]. For NIH3T3 fibroblast cells, growth media consisting of $10 \%$ bovine calf serum (BCS) and 5\% penicillin/streptomycin in DMEM was used. Cells were grown on poly-l-lysine coated cover glass and incubated with low serum media ( $2 \%$ BCS, $5 \%$ penicillin/streptomycin and DMEM) to promote ciliation. To investigate Hedgehog $(\mathrm{Hh})$ signaling in various $\mathrm{pH}_{\mathrm{o}}$, purmorphamine (Sigma-Aldrich, St. Louis, MO, USA) at a final concentration of $10 \mu \mathrm{M}$ was used as a positive control. Purmorphamine was added and incubated for $1 \mathrm{~h}$ with the cells to induce Hh activation.

\subsection{Decreased Extracellular $p H\left(p H_{0}\right)$}

Physiological saline solution (PSS; Table 1) was adjusted to $\mathrm{pH}_{\mathrm{o}} 5.5,6.0,6.5$, and 7.0 from $\mathrm{pH} 7.4$ (control) using $100 \mathrm{mM} \mathrm{HCl}$. For immunoblot, each 35-mm dish was exposed to media of a given $\mathrm{pH}$ for $10 \mathrm{~min}$. Control cells underwent similar treatment with vehicle. Cells were trypsinized and $10^{6}$ cells transferred into $100 \mu \mathrm{L} 2 \times$ Laemelli Sample Buffer (BioRad, Hercules, CA, USA) containing $\beta$-mercaptoethanol. Samples were sonicated and heated at $100{ }^{\circ} \mathrm{C}$ for $5 \mathrm{~min}$. For tracings of $\mathrm{pH}_{\mathrm{i}}$ measurement, BCECF-AM-loaded cells were exposed to media of each $\mathrm{pH}_{0}$, one at a time for $10 \mathrm{~min}$, sequentially from $\mathrm{pH}_{\mathrm{o}} 7.4$ to 5.5 . In all our experiments, we maintained our solution osmolality between 290-300 mOsm/L.

\subsection{Decreased Intracellular $\mathrm{pH}\left(\mathrm{pH}_{i}\right)$}

The $\mathrm{NH}_{4} \mathrm{Cl}$ pulse was used to alter $\mathrm{pH}_{\mathrm{i}}$ using a series of solutions, as previously described [1] and shown in Table 1. All solutions were adjusted to $\mathrm{pH}_{\mathrm{o}} 7.4$ and maintained at $37^{\circ} \mathrm{C}$ with osmolality between 290-300 mOsm/L. PSS was added to the cells for $5 \mathrm{~min}$, then aspirated. The $\mathrm{NH}_{4} \mathrm{Cl}$ solution $\left(20 \mathrm{mM} \mathrm{NH}_{4} \mathrm{Cl}\right)$ was then added to cells until intracellular $\mathrm{pH}$ stabilized, then aspirated. The cells were immediately incubated in $0 \mathrm{~K}^{+} / 0 \mathrm{Na}^{+}$solution, causing dissociation of intracellular $\mathrm{NH}_{4}$, releasing protons into the cytosol, thus decreasing $\mathrm{pH}_{\mathrm{i}} \cdot \mathrm{pH}_{\mathrm{i}}$ recovery was accomplished by adding $5 \mathrm{~K}^{+} / 0 \mathrm{Na}^{+}$ solution $(5 \mathrm{mM} \mathrm{KCl})$ to the cells and incubation in PSS.

Table 1. Composition of solutions used in the $\mathrm{NH}_{4} \mathrm{Cl}$ pre-pulse. Solution names are listed along the first row, and the composition of each is shown in each column. Components of each solution are in $\mathrm{mM}$. HEPES = (4-(2-hydroxyethyl)-1-piperazineethanesulfonic acid); NMDG = N-methyl-D-glucamine.

\begin{tabular}{|c|c|c|c|c|}
\hline Solution & PSS & $\mathrm{NH}_{4} \mathrm{Cl}$ & $0 \mathrm{~K}^{+} / 0 \mathrm{Na}^{+}$ & $5 \mathrm{~K}^{+} / 0 \mathrm{Na}^{+}$ \\
\hline $\mathrm{CaCl}_{2}$ & 1.8 & 1.8 & 1.8 & 1.8 \\
\hline $\mathrm{MgSO}_{4}$ & 0.8 & 0.8 & 0.8 & 0.8 \\
\hline Glucose & 5.5 & 5.5 & 5.5 & 5.5 \\
\hline HEPES & 10 & 10 & 10 & 10 \\
\hline $\mathrm{NaCl}$ & 135 & 0 & 0 & 0 \\
\hline $\mathrm{KCl}$ & 5 & 0 & 0 & 5 \\
\hline $\mathrm{NH}_{4} \mathrm{Cl}$ & 0 & 20 & 0 & 0 \\
\hline NMDG & 0 & 120 & 140 & 135 \\
\hline
\end{tabular}




\subsection{Intracellular $p H$ Measurement}

Intracellular $\mathrm{pH}$ was measured with 2',7'-biscarboxyethy1-5,6-carboxyfluorescein acetoxy-methylester (BCECF-AM; Molecular Probes, \#B1150, Invitrogen, Eugene, OR, USA). Wild-type and $\mathrm{Tg} 737$ cells were incubated with $5 \mu \mathrm{M}$ BCECF-AM for $15 \mathrm{~min}$ at $37^{\circ} \mathrm{C}$. Images were acquired with a Nikon Eclipse Ti-E inverted microscope using $40 \times$ objective and NIS-Elements imaging software (version 4.30, Melville, NY, USA, 2016). Intracellular pH measurements were recorded with emission intensity at wavelength $535 \mathrm{~nm}$. The ratio of emission intensity was determined through excitation wavelengths of $\mathrm{pH}$-dependent $490 \mathrm{~nm}$ and an isosbestic point $440 \mathrm{~nm}$. BCECF fluorescence ratio intensity was calibrated to represent intracellular $\mathrm{pH}$ using $\mathrm{H}^{+}$ionophore nigericin-containing solutions (Sigma-Aldrich, \#N7143). This calibration was performed at the end of each experiment. $20 \mu \mathrm{M}$ nigericin was used to equilibrate $\mathrm{pH}_{\mathrm{o}}$ and $\mathrm{pH}_{\mathrm{i}}$ to $\mathrm{pH}$ values of 5.5, 6.0, 6.5, 7.0 and 7.4. Once the $490 / 440$ ratio for each calibration $\mathrm{pH}$ value was obtained, the ratio values were fitted to a sigmoidal plot. Subsequent experimental ratios were converted to the $\mathrm{pH}$ values.

\subsection{Immunoblot}

All extracellular and intracellular $\mathrm{pH}$ manipulations were performed in the same manner for both $\mathrm{pH}$ measurement and Western blot analysis. $35 \mathrm{~mm}$ dishes were each lysed at different steps of decreased $\mathrm{pH}_{\mathrm{o}}$ or $\mathrm{pH}_{\mathrm{i}}$ with $\mathrm{NH}_{4} \mathrm{Cl}$ pre-pulse. Control cells underwent similar treatment with vehicle. Immunoblot of the lysates was used to analyze the phosphorylation of p38 and ERK1/2 in response to decreased $\mathrm{pH}_{\mathrm{o}}$ or during the different steps of the $\mathrm{NH}_{4} \mathrm{Cl}$ pre-pulse. Blots were probed for $\beta$-actin to confirm equal protein loading. Membranes were blocked for $1 \mathrm{~h}$ then incubated with primary antibody for $2 \mathrm{~h}$. Primary antibodies include: anti-ERK1/2 (Cell Signaling, \#9101), anti-phospho-ERK1/2 (Cell Signaling, \#9102), anti-p38 (Abcam, \#ab7952), anti-phospho-p38 (Abcam, \#ab45381), or anti- $\beta$-actin (CellBioLabs, \#AKR-002). Cells were rinsed $3 \times$ for $10 \mathrm{~min}$ then incubated in secondary antibody for $1 \mathrm{~h}$. Secondary antibodies include anti-mouse IgG, HRP-linked (Cell Signaling Technologies, \#7076) or anti-rabbit IgG, HRP-linked (Cell Signaling Technologies, \#7074). After rinsing three times for 10 min each, membranes were visualized using SuperSignaling West Pico Luminol Enhancers solution (Thermo Scientific, \#1859675) and detected with the ChemiDoc from BioRad. Images were acquired and analyzed using ImageLab3.0 software.

\subsection{Primary Cilia Immunostaining}

Cells were grown to confluence on coverslips according to the cell culture conditions mentioned above. The cells were then exposed to media with $\mathrm{pH}$ of 5.5, 6.0, 6.5, 7.0 and 7.4 (control) for $5 \mathrm{~min}$. The cells were fixed using 4\% paraformaldehyde and 2\% sucrose in PBS for $10 \mathrm{~min}$ and permeabilized for $5 \mathrm{~min}$ in $10 \%$ Triton X-100. The cells were incubated with Gli antibody (1:200 dilution in PBS, Abcam, Cambridge, MA, USA) for $16 \mathrm{~h}$ at $4{ }^{\circ} \mathrm{C}$, acetylated- $\alpha$-tubulin (1:10,000 dilution in PBS, Sigma Aldrich, St. Louis, MO, USA) for $1 \mathrm{~h}$ at $27^{\circ} \mathrm{C}$ followed by fluorescein isothiocyanate (FITC)-conjugated anti-mouse antibody then Texas-red conjugated anti-rabbit antibody (1:1000 dilution in PBS, Vector Labs Burlingame, CA) for $1 \mathrm{~h}$ at $27^{\circ} \mathrm{C}$. Slides were mounted with DAPI hard set mounting media (Southern Biotech, Birmingham, AL, USA). Images were acquired using a Nikon Eclipse Ti-E inverted microscope with the NIS-Elements imaging software (version 4.30) in 100x magnification fields with z-stack slices of $0.25 \mu \mathrm{m}$. Flat cilia defined by consistent length in four z-slices were measured [31]. The majority of our cilia were flattened on the slide surface, and cilia were measured in three-dimensionally (3D). To ensure cilia flattened on the surface, we included a 3D movie in the supplement (Supplement Movie). We used Nikon NIS-Elements for Advanced Research software to capture and measure all cilia length in 3D. This software package included pre-programmed length analysis through iterations of automatic object recognition followed by image scanning and segmentation, optical flow and 3D object reconstruction. The single-particle tracking was 
activated only when cilia length was less than $1 \mu \mathrm{m}$, especially in $T g 737$ cells. In such cases (wild-type and $\operatorname{Tg} 737$ cells), cells with less than $1 \mu \mathrm{m}$ length of cilia were denoted as non-ciliated cells.

Length measurements of 150 primary cilia was randomly selected using NIS-Elements. To obtain number of cells possessing cilia, six random 100x fields were scanned and a maximum intensity projection created for each field. The total number of cilia and nuclei, as a representation of cell number, was used to calculate ciliated cell percentage. Statistical analysis was performed on Prism GraphPad 8.1.2 software (GraphPad, San Diego, CA, USA).

\subsection{Scanning Electron Microscopy}

Cells were fixed with $2.5 \%$ paraformaldehyde/glutaraldehyde in sodium cacodylate buffer for $1 \mathrm{~h}$ at $27^{\circ} \mathrm{C}$. Samples were post-fixed with $1 \%$ aqueous osmium tetroxide solution. Dehydration was done using ethanol solutions. Samples were further dried with a 2-h incubation in 50\% hexamethyldisilazane (HMDS)-ethyl alcohol mixture, followed by two 30-min incubations in 100\% HMDS. Micrographs were obtained and analyzed using a Hitachi HD-2300 scanning electron microscope (SEM) [24].

\subsection{Data Analysis}

The rate of $\mathrm{pH}_{\mathrm{i}}$ changes is denoted as a rate constant of $\Delta \mathrm{pH}_{\mathrm{i}}$ and expressed as $\mathrm{dpH} / \mathrm{dt}$ $\left(\Delta \mathrm{pH}_{\mathrm{i}}\right.$ units/min). Because the $\Delta \mathrm{pH}_{\mathrm{i}}$ is defined as rate constant of $\mathrm{pH}_{\mathrm{i}}$ decreased with respect to time, this $\mathrm{pH}_{\mathrm{i}}$ was not necessarily decreased at a constant speed. In other words, the changes in $\mathrm{pH}_{\mathrm{i}}$ could speed up and slow down during the period of measurement. We, therefore, looked at a second order kinetics of these acceleration and deceleration events. The second order kinetics were determined through the tangential rates in the changes of rate constant of $\Delta \mathrm{pH}_{\mathrm{i}}$ using Microsoft Excel software (version 15.32). The mathematical expression to calculate the change of function $f$ at the time $t 1$ is as follows:

$$
\text { Changes in Rate Constant of } \Delta p H i=f^{\prime}(t 1)=\lim _{t 2 \rightarrow t 1} \frac{f(t 2)-f(t 1)}{t 2-t 1}
$$

All the data shown are mean \pm SEM from at least three independent experiments. Data was analyzed using ANOVA test followed by Tukey post-hoc test for multiple groups with $p<0.05$ being considered as significant. Analysis of data was performed with Prism GraphPad 7 software (GraphPad, San Diego, CA, USA).

\section{Results}

\subsection{Intracellular Acidosis in Response to Decreasing $\mathrm{pH}_{0}$ in Wild-Type and Tg737 Cells}

Incubation of cells in PSS of decreasing extracellular $\mathrm{pH}\left(\mathrm{pH}_{\mathrm{o}}\right)$ from 7.4 to 5.5 acidified the intracellular environment in both wild-type (Figure 1a) and cilia-less Tg737 cells (Figure 1b). The acidic $\mathrm{pH}_{\mathrm{o}}$ mediated decrease in $\mathrm{pH}_{\mathrm{i}}$ was similar in both wild-type and $\mathrm{Tg} 737$ cells (Figure 1c). The rate of $\mathrm{pH}_{\mathrm{i}}$ changes $\left(\Delta \mathrm{pH}_{\mathrm{i}}\right)$ was not significantly different between wild-type and $T g 737$ cells (Figure 1d). The negative values of $\Delta \mathrm{pH}_{\mathrm{i}}$ indicated that the $\mathrm{pH}_{\mathrm{i}}$ was decreased in acidified media. There was no significant different between wild-type and $T g 737$ cells in the uniformity of or changes in $\Delta \mathrm{pH}_{\mathrm{i}}\left(\Delta \Delta \mathrm{pH}_{\mathrm{i}} ;\right.$ Figure 1e). The positive values of $\Delta \Delta \mathrm{pH}_{\mathrm{i}}$ indicated that the $\Delta \mathrm{pH}_{\mathrm{i}}$ was predominantly involved in acceleration to decrease $\mathrm{pH}_{\mathrm{i}}$. 

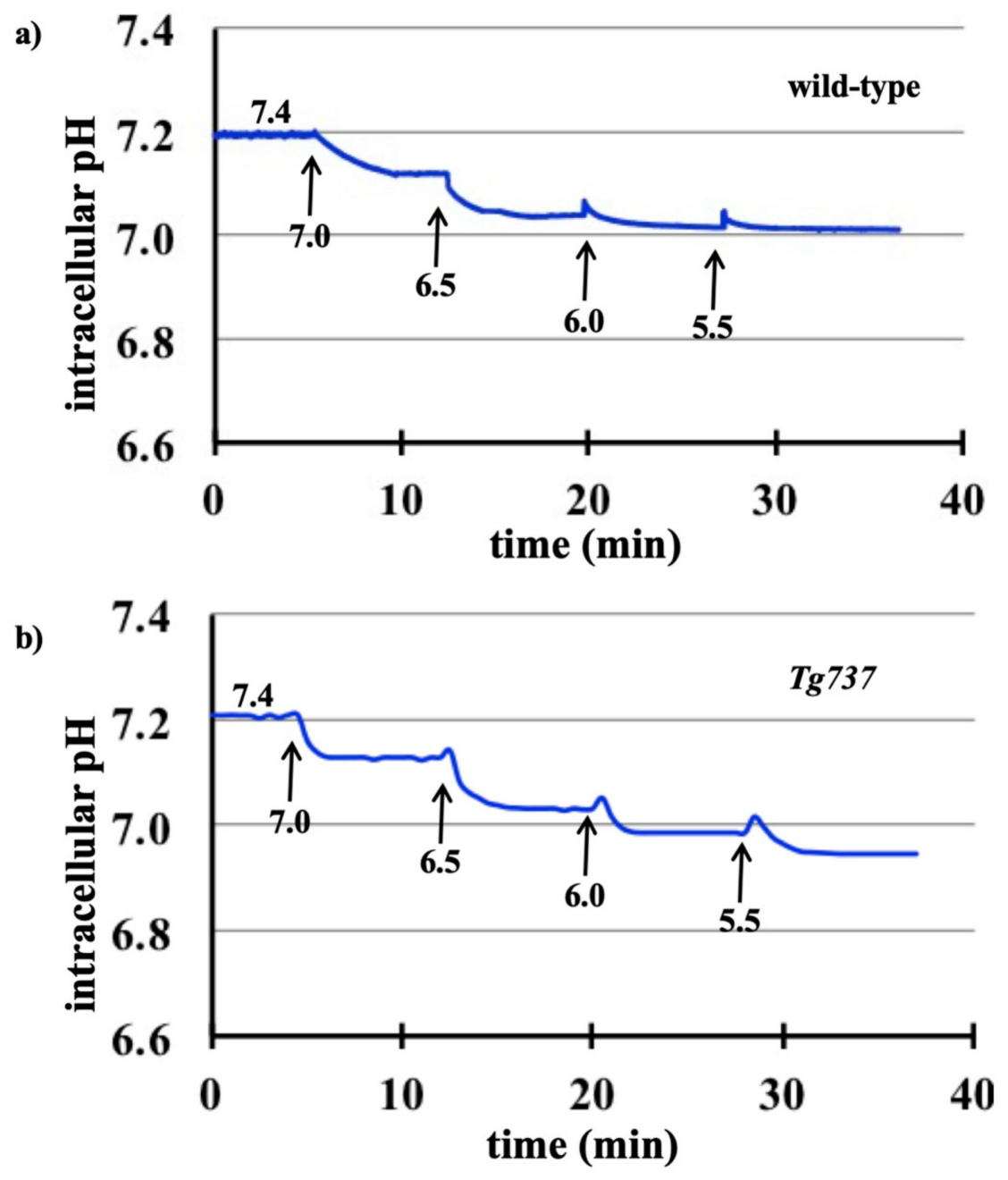

Figure 1. Cont. 
c)

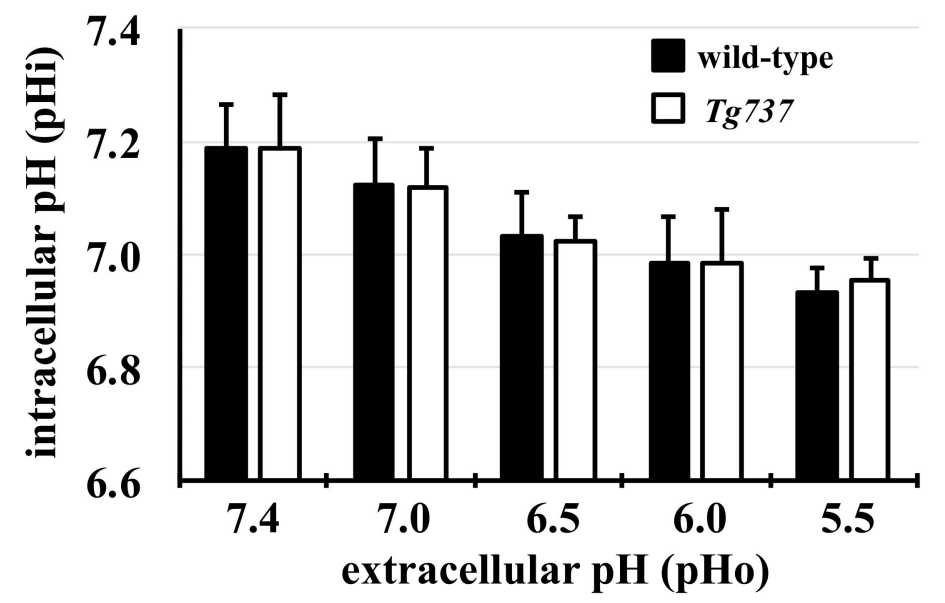

d)
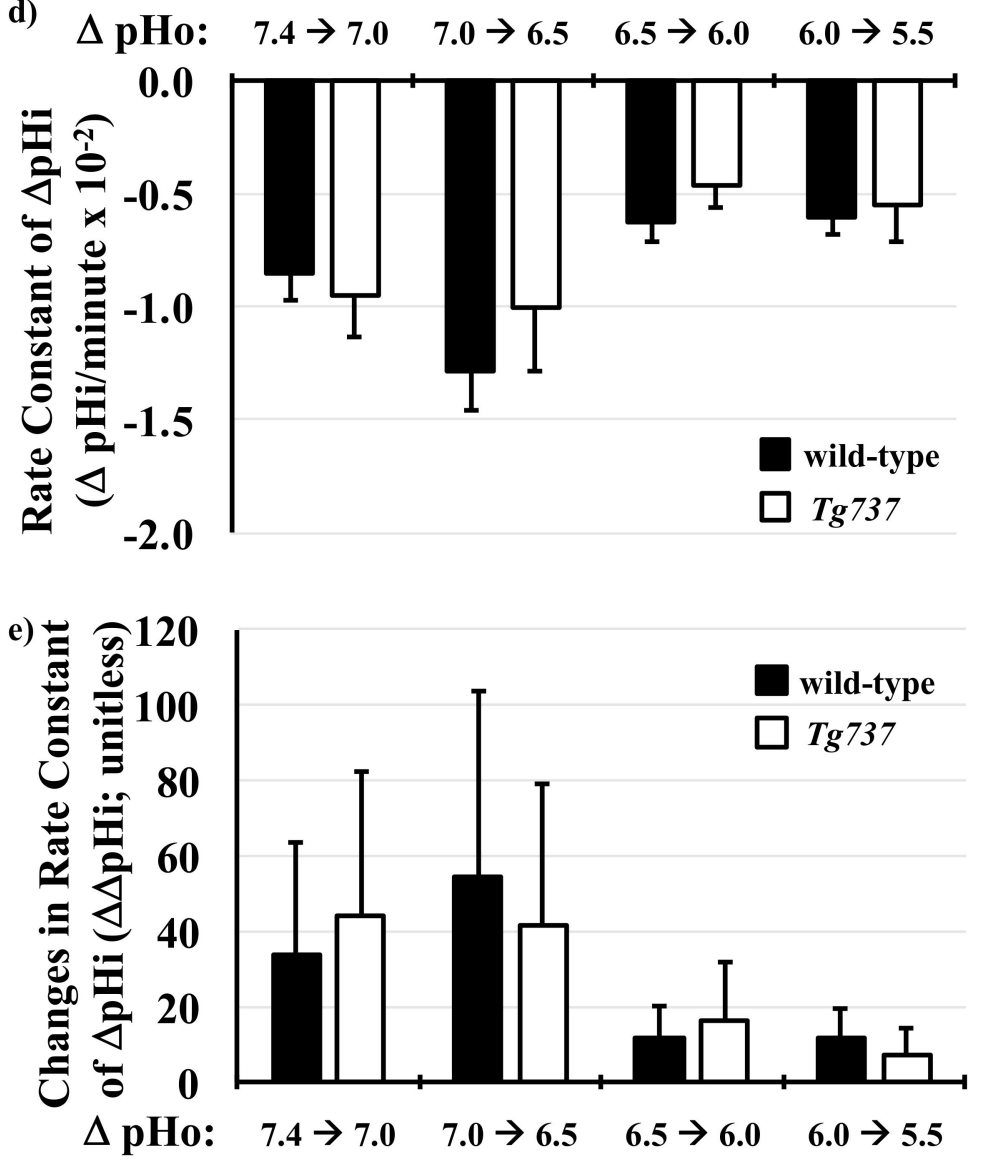

Figure 1. Decreased intracellular $\mathrm{pH}$ in response to acidic extracellular $\mathrm{pH}$ in wild-type and $\mathrm{Tg} 737$ cells. $(\mathbf{a}, \mathbf{b})$ Representative tracings of changes in intracellular $\mathrm{pH}_{\mathrm{i}}$ when wild-type and $\mathrm{Tg} 737$ cells are exposed to media of decreasing extracellular $\mathrm{pH}\left(\mathrm{pH}_{\mathrm{o}}\right)$ from 7.4 to 5.5. (c) As the $\mathrm{pH}_{\mathrm{o}}$ is decreased, both cell lines show a similar decrease in their $\mathrm{pH}_{\mathrm{i}}$. (d) The rate constant $\mathrm{pH}_{\mathrm{i}}$ changes $\left(\Delta \mathrm{pH}_{\mathrm{i}}\right)$ in response step changes in $\mathrm{pH}_{\mathrm{o}}$ are also similar in both cell lines. A negative value indicates a decrease in $\mathrm{pH}_{\mathrm{i}}$. (e) Changes in $\Delta \mathrm{pH}_{\mathrm{i}}\left(\Delta \Delta \mathrm{pH}_{\mathrm{i}}\right)$ are normalized to identify variability within $\Delta \mathrm{pH}_{\mathrm{i}}$ in response to step changes in $\mathrm{pH}_{\mathrm{o}}$. No variation is observed if there is no acceleration or deceleration (first order kinetic or $\Delta \Delta \mathrm{pH}_{\mathrm{i}}=0$ ). Highest variation $\left(\Delta \Delta \mathrm{pH}_{\mathrm{i}}=100\right)$ indicates that an alternate acceleration-deceleration pattern occurred (if acceleration $=$ deceleration, then $\Delta \mathrm{pH}_{\mathrm{i}}=0$ ).

To validate that primary cilia remained intact and structurally stable in acidified media, endothelial cilia were examined with ciliary marker acetylated- $\alpha$-tubulin (Figure 2a). To examine the effect of 
extracellular $\mathrm{pH}$ on the length of primary cilia, the distribution of cilia length as well as ciliation frequency is tabulated in the bar graph (Figure 2b). Compared to control at pH 7.4, a small but significant increase in cilia length was observed at $\mathrm{pH}_{\mathrm{o}}$ of 7.0, 6.5 and 5.5 while there were no significant differences observed in ciliation frequency (Figure 2c). There were no apparent differences in the cilia formation at different extracellular $\mathrm{pH}$ levels. Approximately $80-85 \%$ of wild-type cells were ciliated in acidified media, as well as at $\mathrm{pH} 7.4$. For cilia-less $\mathrm{Tg} 737$ cells, the only representative image at $\mathrm{pH} 7.4$ is shown with no further apparent differences in acidified media. There were no cilia length increase in $T g 737$ cells at various $\mathrm{pH}_{\mathrm{i}}$.

Most importantly, the data shows that wild-type cells continued to possess primary cilia without any structural aberrations in an acidic environment. Further validation with another ciliated cell line, NIH3T3, was conducted to observe changes in ciliary length or ciliation frequency when challenged with acidified media (Supplement Figure S1-S3). Lower acidic media was able to significantly increase ciliary length at $\mathrm{pH}_{\mathrm{o}}$ of 6.5 and 5.5 while ciliation frequency remained unchanged at lower $\mathrm{pH}_{\mathrm{o}}$. Among the many signaling activities related to the primary cilia, Hedgehog signaling (Hh) is unique in translocating activated receptors and proteins to the cilia [32]. To observe changes in functional role of the primary cilia under our experimental conditions, we used purmophamine to activate the Hh pathway. After observing no effect of Hh activation on ciliary length or ciliation frequency of the cells, we studied if acidified media induced Hh signaling, as shown by Gli translocation to the ciliary tip in NIH3T3 cells (Supplement Figure S3). There is also no apparent structural defect in cilia following a decrease in intracellular pH (Supplement Figure S4).

a)
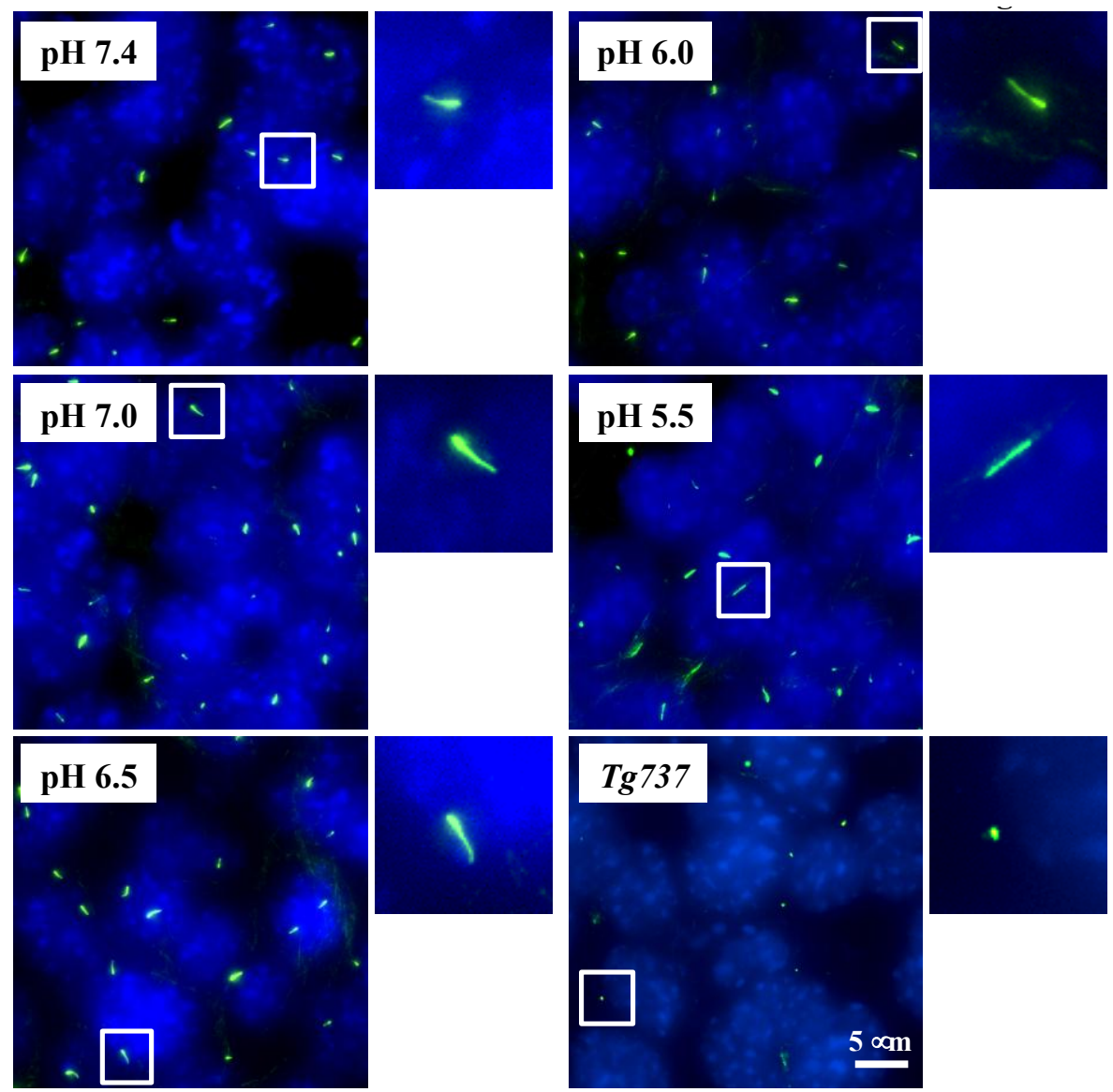

Figure 2. Cont. 

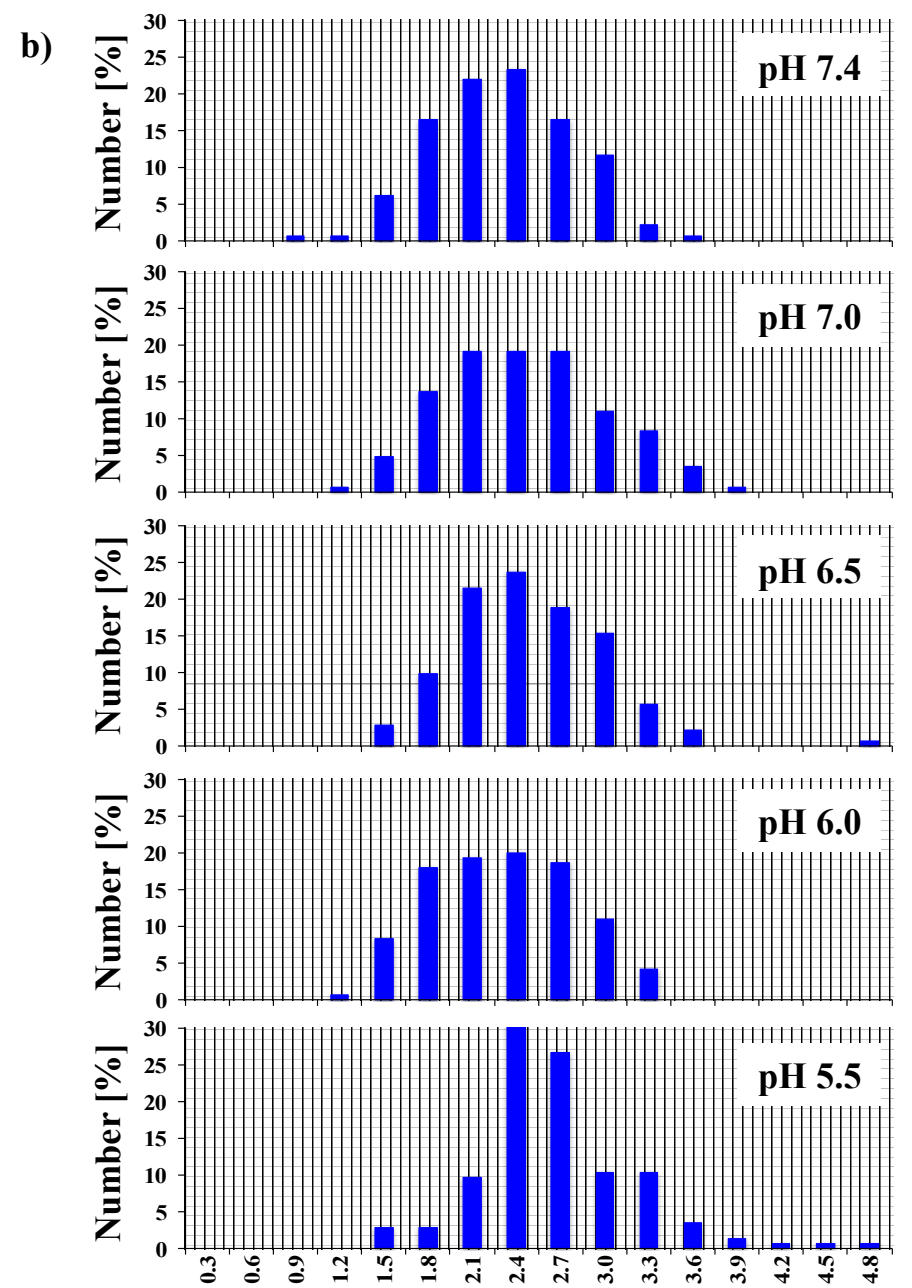

Cilia Length (ळm)

c)
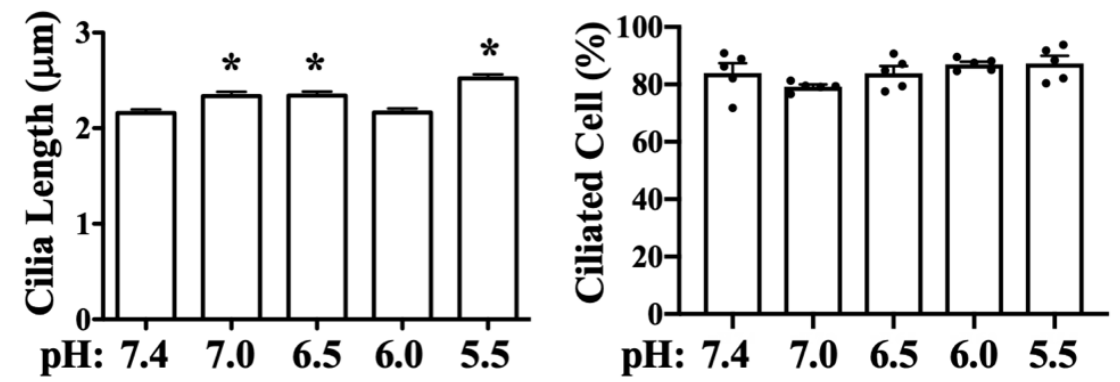

Figure 2. Immunofluorescence staining to study effects of $\mathrm{pH}_{\mathrm{O}}$ on primary cilia. (a) Cells (wild-type and $T g 737$ ) were stained with ciliary marker (acetylated- $\alpha$-tubulin; green) and nucleus marker (DAPI; blue). Representative images are shown for wild-type cells at different $\mathrm{pH}_{\mathrm{o}}$ and $\mathrm{Tg} 737$ at $\mathrm{pH}_{\mathrm{o}}$ 7.4. White boxes show enlargement of the images to depict the presence of primary cilia. (b) The lengths of primary cilia from 50 cells were measured from each preparation $(\mathrm{N}=3)$ and illustrated in the bar graph to depict length distribution within each $\mathrm{pH}_{\mathrm{o}}$. (c) Cilia length was averaged from 150 cells $(\mathrm{N}=3$; each with 50 randomly selected cells) and the number of cells possessing cilia represented as a percentage with each point representing an individual experimental datapoint. * indicates a significant difference to control $\mathrm{pH}_{\mathrm{o}} 7.4$. 


\subsection{MAPK Activation in Response to Decreasing $p H_{0}$ in Wild-Type and Tg737 Cells}

Both wild-type and $\mathrm{Tg} 737$ cells exhibited MAPK phosphorylation in response to decreased $\mathrm{pH}_{\mathrm{o}}$. Significant increase of ERK1/2 phosphorylation occurred at $\mathrm{pH}_{\mathrm{o}} 6.5$ in wild-type cells (178\% increase versus control $\left.\mathrm{pH}_{\mathrm{o}} 7.4\right)$ and persisted at $\mathrm{pH}_{\mathrm{o}} 6.0$ and $\mathrm{pH}_{\mathrm{o}} 5.5(227 \%$ and $189 \%$ increase in ERK1/2 phosphorylation, respectively versus control $\mathrm{pH}_{\mathrm{o}}$ 7.4) (Figure 3a). ERK1/2 phosphorylation occurred at $\mathrm{pH}_{\mathrm{o}} 6.0$ in $\mathrm{Tg} 737$ cells ( $140 \%$ increase versus control $\mathrm{pH}_{\mathrm{o}}$ 7.4) (Figure $3 \mathrm{~b}$ ). Another MAPK, $\mathrm{p} 38$ was phosphorylated at $\mathrm{pH}_{\mathrm{o}} 7.0$ in wild-type cells $\left(242 \%\right.$ increase versus control $\left.\mathrm{pH}_{\mathrm{o}} 7.4\right)$ and persisted at $\mathrm{pH}_{\mathrm{o}} 6.0$ and $\mathrm{pHo} 5.5$ (227\% and $189 \%$ increase in p38 phosphorylation, respectively versus control $\mathrm{pH}_{\mathrm{o}}$ 7.4) (Figure 4a). $\mathrm{p} 38$ phosphorylation occurred at $\mathrm{pH}_{\mathrm{o}} 6.5$ in $\mathrm{Tg} 737$ cells (393\% increase versus control $\left.\mathrm{pH}_{\mathrm{o}} 7.4\right)$ and persisted through $\mathrm{pH}_{\mathrm{o}} 5.5(321 \%$ and $360 \%$ increase in $\mathrm{p} 38$ phosphorylation at $\mathrm{pH}_{\mathrm{o}} 6.0$ and 5.5, respectively, versus control $\mathrm{pH}_{\mathrm{o}}$ 7.4) (Figure $4 \mathrm{~b}$ ). $\mathrm{Tg} 737$ cells required higher acidic conditions to increase MAPK phosphorylation than the wild-type cells. There did not seem to be a significant impairment in cilia-less $T g 737$ cells' ability to sense and respond to decreased $\mathrm{pH}_{0}$, but we find a lower $\mathrm{pH}$ threshold for activation of MAPK in Tg737 compared to wild-type cells.

a)

wild-type

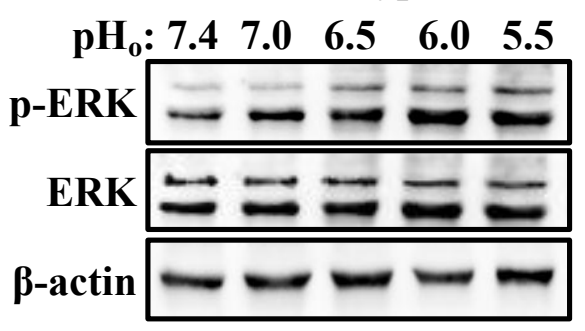

b)

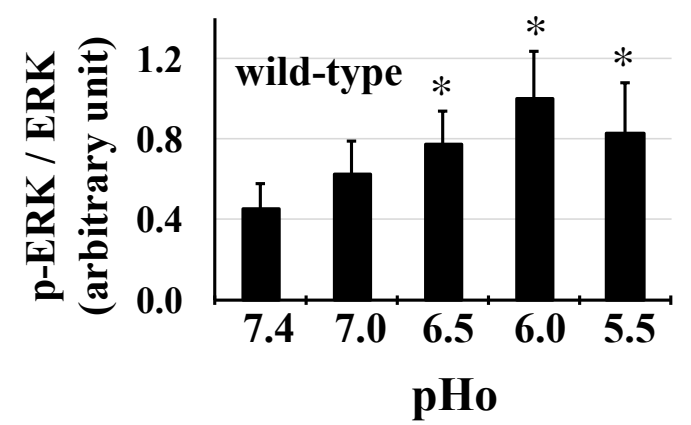

$\operatorname{Tg} 737$
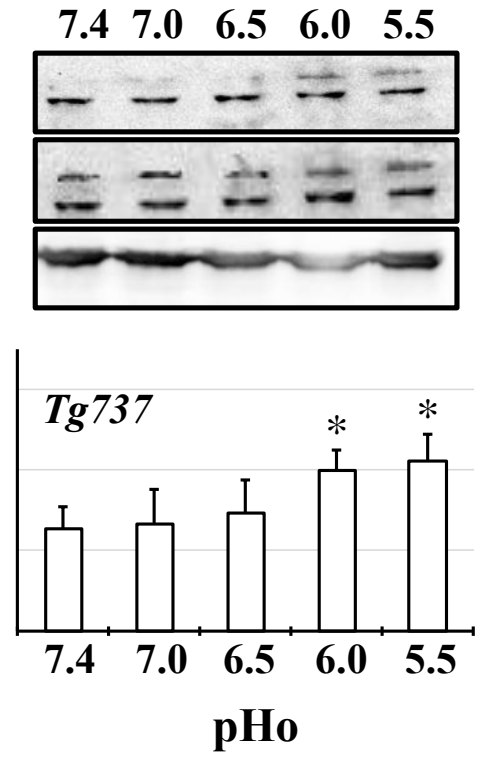

Figure 3. Decreasing extracellular $\mathrm{pH}$ increases ERK1/2 phosphorylation in wild-type and $\mathrm{Tg} 737$ cells. (a) Representative immunoblots show ERK1/2 phosphorylation in wild-type and Tg737 cells as they are exposed to media of decreasing extracellular $\mathrm{pH}\left(\mathrm{pH}_{\mathrm{o}}\right)$ from 7.4 to 5.5. (b) Bar graph shows the mean p-ERK/ERK, where wild-type cells phosphorylate ERK1/2 at $\mathrm{pH}$ of 6.5 while the same level of phosphorylation occurs at a lower $\mathrm{pH}$ of $6.0 .{ }^{*}$ indicates $p<0.05$ as compared to control $\mathrm{pH}_{\mathrm{o}} 7.4$; $\mathrm{N}=10$ for wild-type cells and $\mathrm{N}=10$ for $\mathrm{Tg} 737$ cells. 
a)

wild-type

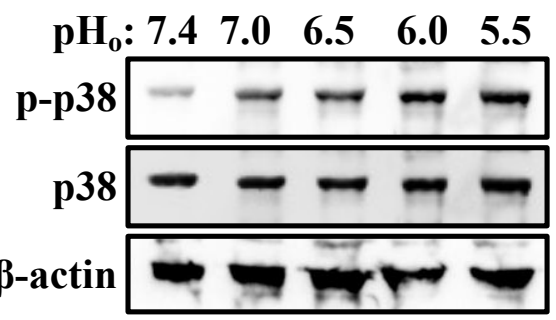

b)

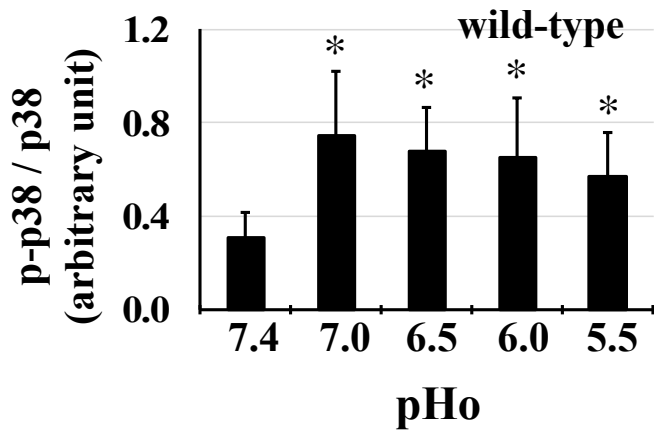

$\operatorname{Tg} 737$

$\begin{array}{lllll}7.4 & 7.0 & 6.5 & 6.0 & 5.5\end{array}$

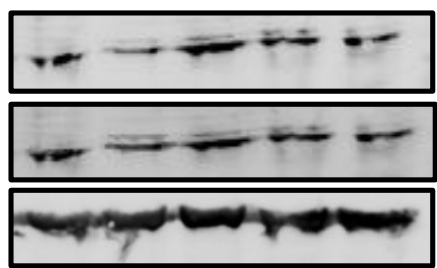

$\operatorname{Tg} 737$

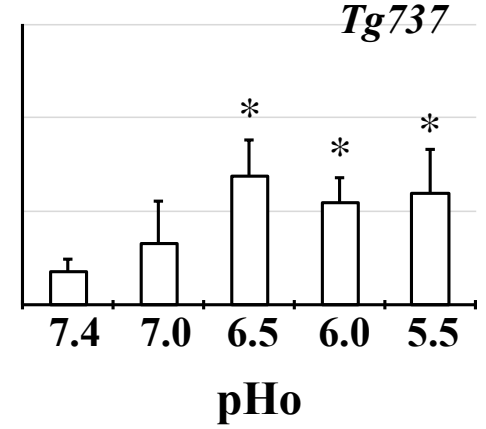

Figure 4. p38 phosphorylation by decreased extracellular $\mathrm{pH}$ in wild-type and $\mathrm{Tg} 737$ cells. (a) Representative immunoblots show p38 phosphorylation in wild-type and $\mathrm{Tg} 737$ cells as they are exposed to media of decreasing extracellular $\mathrm{pH}\left(\mathrm{pH}_{\mathrm{o}}\right)$ from 7.4 to 5.5. (b) Bar graph shows mean p-p38/p38. Significant increase in $\mathrm{p}-38$ phosphorylation occurs when $\mathrm{pH}$ changes from 74 . to 7.0. But in Tg737 cells the $\mathrm{pH}$ had to drop to 6.5 before significant changes in p38 phosphorylation was observed. * indicates $p<0.05$ as compared to control $\mathrm{pH}_{\mathrm{O}} 7.4 ; \mathrm{N}=8$ for wild-type cells and $\mathrm{N}=8$ for Tg737 cells.

\section{3. $\mathrm{NH}_{4} \mathrm{Cl}$ Pre-Pulse Induces Intracellular Acidosis in Wild-Type and Tg737 Cells}

To eliminate the effect of $\mathrm{pH}_{\mathrm{o}}$ and observe intracellularly restricted $\mathrm{pH}$ acidosis $\mathrm{NH}_{4} \mathrm{Cl}$ pre-pulse was used to lower $\mathrm{pH}_{\mathrm{i}}$. Changes in $\mathrm{pH}_{\mathrm{i}}$ during the $\mathrm{NH}_{4} \mathrm{Cl}$ pre-pulse using $\mathrm{Na}^{+}$- and $\mathrm{K}^{+}$-containing PSS for $\mathrm{pH}_{\mathrm{i}}$ recovery are depicted in representative tracings (Figure $5 \mathrm{a}, \mathrm{b}$ of wild-type and $\mathrm{Tg} 737$ cells, respectively) and data is summarized in Figure 5c. In wild-type cells, $\mathrm{NH}_{4} \mathrm{Cl}$ caused an increase in intracellular $\mathrm{pH}\left(0.014 \pm 0.002 \mathrm{pH}\right.$ units/min); in $\mathrm{Tg} 737$ cells, $\mathrm{NH}_{4} \mathrm{Cl}$ also increased the $\mathrm{pH}_{\mathrm{i}}$ $(0.019 \pm 0.003 \mathrm{pH}$ units $/ \mathrm{min})$. In the absence of sodium and potassium, the $\mathrm{pH}_{\mathrm{i}}$ decreased in both cell types $(0.028 \pm 0.004 \mathrm{pH}$ units/min in wild-type cells and $0.020 \pm 0.003 \mathrm{pH}$ units $/ \mathrm{min}$ in $\mathrm{Tg} 737$ cells, from $\mathrm{NH}_{4} \mathrm{Cl}$ conditions). $\mathrm{pH}_{\mathrm{i}}$ recovery occurred upon addition of the $\mathrm{Na}^{+}$- and $\mathrm{K}^{+}$-containing PSS solution, at a rate of $0.006 \pm 0.0001 \mathrm{pH}$ units/min in wild-type cells, and more significantly in Tg737 cells at a rate of $0.031 \pm 0.003 \mathrm{pH}$ units $/ \mathrm{min}$, from $0 \mathrm{~K}^{+} / 0 \mathrm{Na}^{+}$conditions. Because rates did not increase during incubation in the $0 \mathrm{~K}^{+} / 0 \mathrm{Na}^{+}$solution, $\mathrm{Na}^{+}$- or $\mathrm{K}^{+}$-dependent transport is likely responsible for endothelial cells' recovery from decreased $\mathrm{pH}_{\mathrm{i}}$. Another inference is that $\mathrm{Na}^{+}$- and $\mathrm{K}^{+}$-independent transport may not be present or activated by intracellular acidosis, in vascular endothelial cells.

To validate that primary cilia remained intact and structurally stable after intracellular acidification independent of $\mathrm{pH}_{\mathrm{O}}$, endothelial cilia were examined with ciliary marker acetylated- $\alpha$-tubulin (Supplement Figure S5). To examine the effect of $\mathrm{pH}_{\mathrm{i}}$ acidification on the length of primary cilia, the distribution of cilia length as well as ciliation frequency is tabulated in the bar graph (Supplement Figure S6). Compared to control at $\mathrm{pH}_{\mathrm{i}} 7.4$, a small but significant decrease in cilia length was observed at $\mathrm{pH}_{\mathrm{i}}$ of 7.0 while there were no significant differences observed in ciliation frequency. There were no apparent differences in the cilia formation between $\mathrm{pH}_{\mathrm{i}} 7.4$ and 7.0. Approximately $80-85 \%$ of wild-type cells were ciliated. There were no cilia length recovery in $T g 737$ cells at $\mathrm{pH}_{\mathrm{i}}$ of 7.0. 
a)

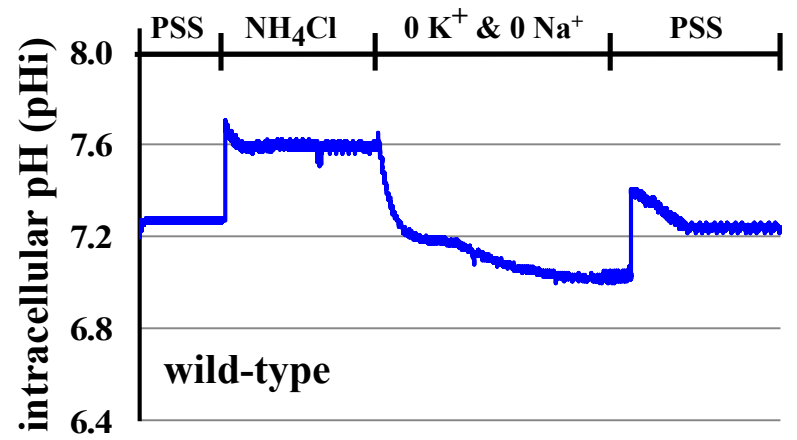

b)

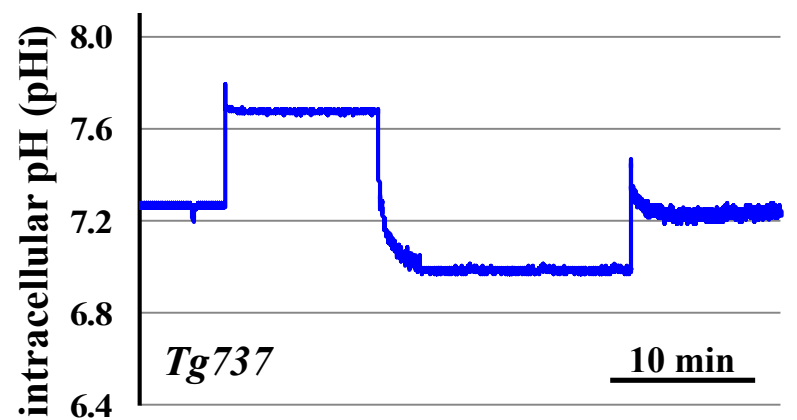

c)

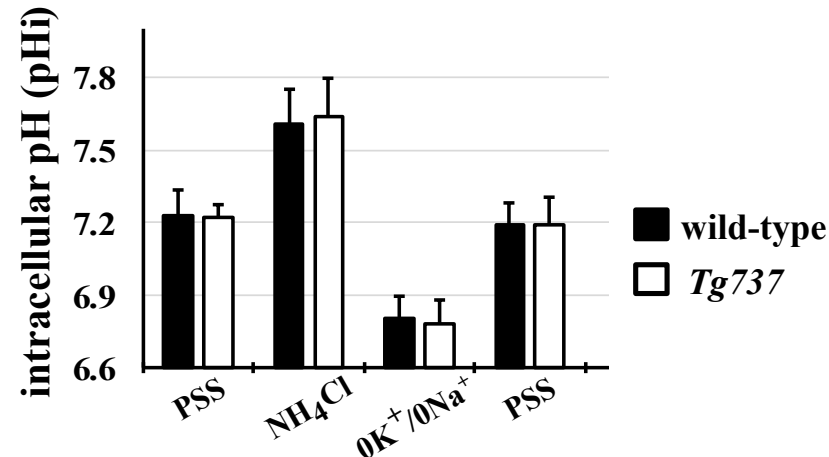

Figure 5. Changes in $\mathrm{pH}_{\mathrm{i}}$ during the $\mathrm{NH}_{4} \mathrm{Cl}$ pre-pulse in wild-type and $\mathrm{Tg} 737$ cells. (a,b) Representative tracings of changes in intracellular $\mathrm{pH}$ when wild-type and $\mathrm{Tg} 737$ cells are exposed to solutions of the $\mathrm{NH}_{4} \mathrm{Cl}$ pre-pulse in $\mathrm{Na}^{+}$- and $\mathrm{K}^{+}$-devoid solution for $\mathrm{pH}_{\mathrm{i}}$ recovery. (c) Bar graph shows the summary of mean changes in $\mathrm{pH}_{\mathrm{i}}$ recovery in wild-type and $T g 737$ cells. $\mathrm{N}=5$ for wild-type cells and $\mathrm{N}=3$ for Tg737 cells.

\subsection{Intracellular Acidosis Activates MAPK Signaling Pathways}

MAPK phosphorylation during the $\mathrm{NH}_{4} \mathrm{Cl}$ pre-pulse was similar in both cell types, with slight variations (Figure 6a). ERK1/2 phosphorylation at acid $\mathrm{pH}_{\mathrm{i}}$ during the $0 \mathrm{~K}^{+} / 0 \mathrm{Na}^{+}$step of the $\mathrm{NH}_{4} \mathrm{Cl}$ pre-pulse occurred in only wild-type cells (3.7-fold increase in ERK1/2 phosphorylation versus control conditions) (Figure $6 \mathrm{~b}$ ). ERK1/2 phosphorylation was observed during $\mathrm{pH}_{\mathrm{i}}$ recovery in both wild-type and $T g 737$ cells (2.1-fold and 2.3-fold respective increases in phosphorylation versus control conditions). p38 phosphorylation pattern varied between the wild type and cilia-less $T g 737$ as well. In wild-type cells, p38 phosphorylation occurred at low $\mathrm{pH}_{\mathrm{i}}$ during the $0 \mathrm{~K}^{+} / 0 \mathrm{Na}^{+}$step of the $\mathrm{NH}_{4} \mathrm{Cl}$ pre-pulse (10-fold increase in phosphorylation versus control conditions); in Tg737 cells, p38 phosphorylation was dampened, occurring only during $\mathrm{pH}_{\mathrm{i}}$ recovery (4.0-fold increase in p38 phosphorylation versus control conditions) (Figure 6c). 


\section{wild-type}

a)

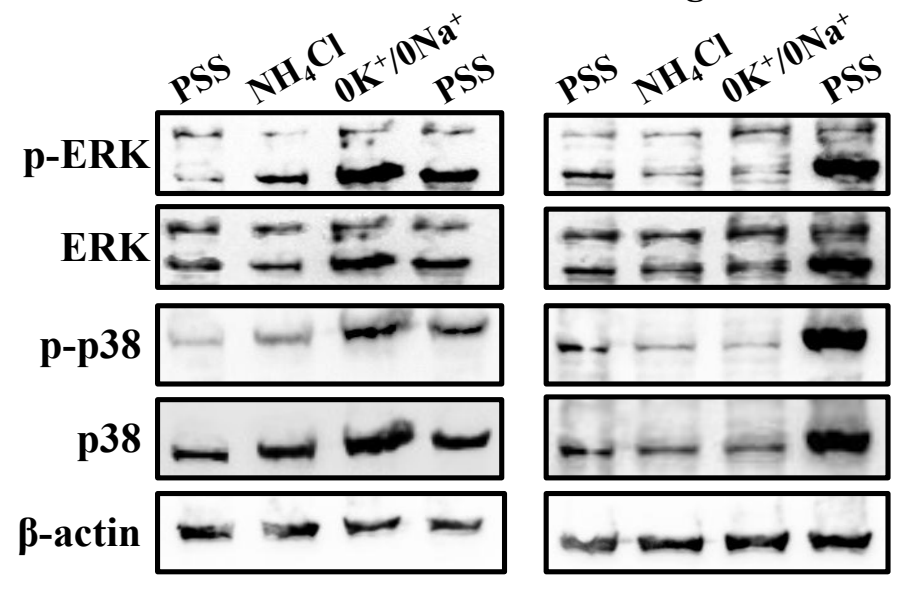

b)

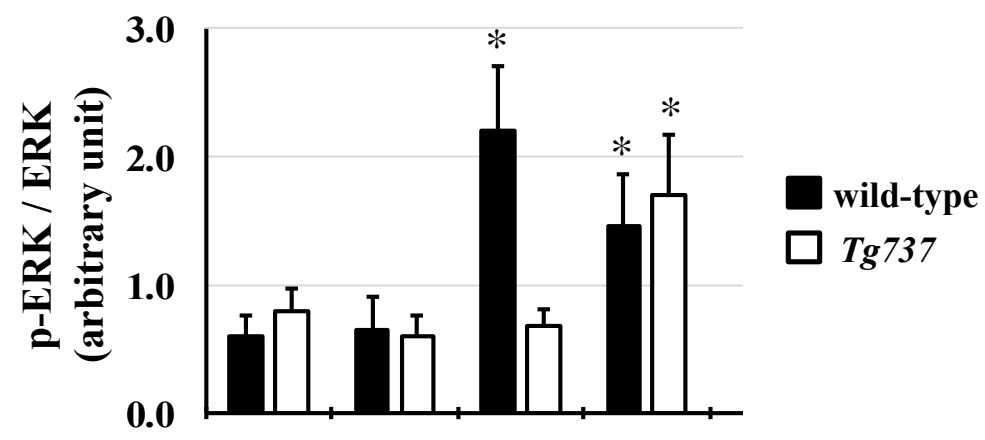

c)

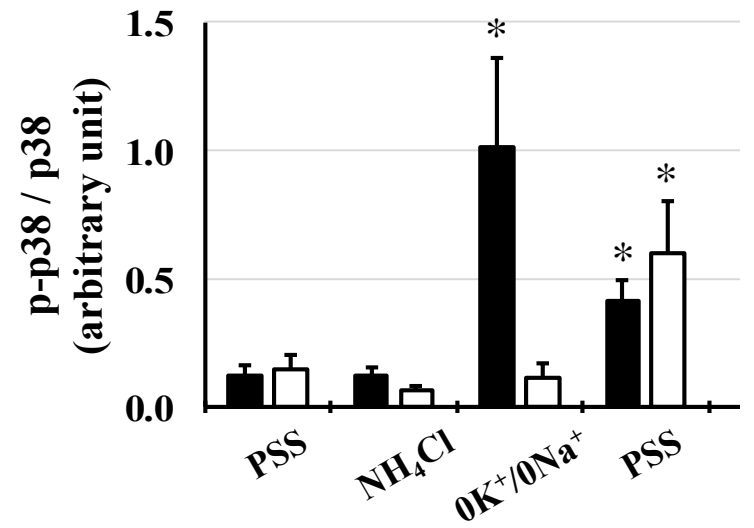

Figure 6. ERK1/2 and p38 phosphorylation during the $\mathrm{NH}_{4} \mathrm{Cl}$ pre-pulse in wild-type and $\mathrm{Tg} 737$ cells. (a) Representative immunoblots show ERK1/2 and p38 phosphorylation in wild-type and Tg737 cells as they are exposed to different solutions during the $\mathrm{NH}_{4} \mathrm{Cl}$ pre-pulse. $(\mathbf{b}, \mathbf{c})$ Bar graphs show mean p-ERK/ERK and p-p38/p38. * indicates $p<0.05$ as compared to control conditions; for ERK1/2 $\mathrm{N}=6$ for wild-type cells and $\mathrm{N}=5$ for Tg737 cells; for $\mathrm{p} 38 \mathrm{~N}=5$ for wild-type cells and $\mathrm{N}=5$ for Tg737 cells.

3.5. Effects of $\mathrm{K}^{+}$on $\mathrm{pH} \mathrm{H}_{i}$ Recovery and on MAPK Phosphorylation during the $\mathrm{NH}_{4} \mathrm{Cl}$ Pre-Pulse in Wild-Type and Tg737 Cells

Potassium-containing $5 \mathrm{~K}^{+} / 0 \mathrm{Na}^{+}$solution could be used to study $\mathrm{K}^{+}$-dependent $\mathrm{pH}_{\mathrm{i}}$ recovery [1]. When the $\mathrm{NH}_{4} \mathrm{Cl}$ pre-pulse was expanded to include potassium-containing $5 \mathrm{~K}^{+} / 0 \mathrm{Na}^{+}$solution in between the $0 \mathrm{~K}^{+} / 0 \mathrm{Na}^{+}$and PSS solutions during $\mathrm{pH}_{\mathrm{i}}$ recovery, the $\mathrm{pH}_{\mathrm{i}}$ increased very rapidly in wild-type cells and $\mathrm{Tg} 737$ cells, highlighting the importance of $\mathrm{K}^{+}$-dependent transporter activity during $\mathrm{pH}_{\mathrm{i}}$ recovery in vascular endothelial cells, shown in representative tracings in Figure 7a,b, and summarized in Figure 7c. Addition of potassium-containing $5 \mathrm{~K}^{+} / 0 \mathrm{Na}^{+}$solution drove the $\mathrm{pH}_{\mathrm{i}}$ up in both cell types $(0.030 \pm 0.003 \mathrm{pH}$ units $/ \mathrm{min}$ in wild-type cells and $0.035 \pm 0.003 \mathrm{pH}$ units in Tg737 
cells, versus $0 \mathrm{~K}^{+} / 0 \mathrm{Na}^{+}$conditions). Interestingly, addition of PSS at the end of the pulse returned the $\mathrm{pH}_{\mathrm{i}}$ to a normal level by driving the $\mathrm{pH}_{\mathrm{i}}$ down at a rate of $0.036 \pm 0.005 \mathrm{pH}$ units/min in wild-type cells and $0.035 \pm 0.006 \mathrm{pH}$ units $/ \mathrm{min}$ in $\mathrm{Tg} 737$ cells, from $5 \mathrm{~K}^{+} / 0 \mathrm{Na}^{+}$conditions.

a)

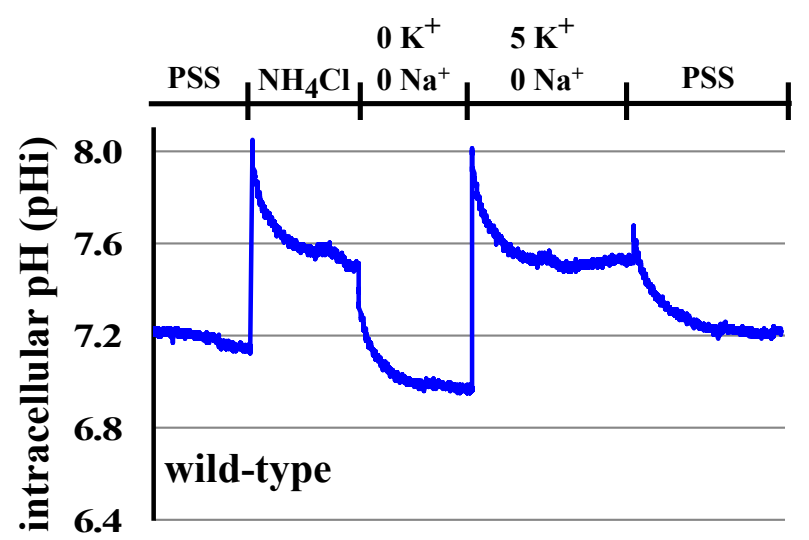

b)

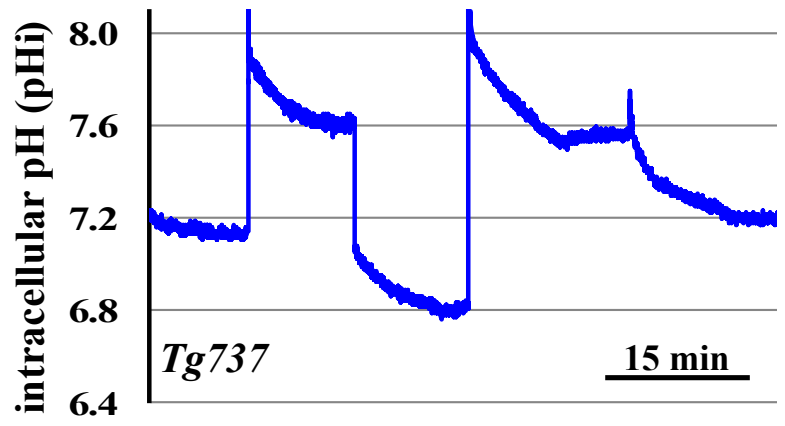

c)

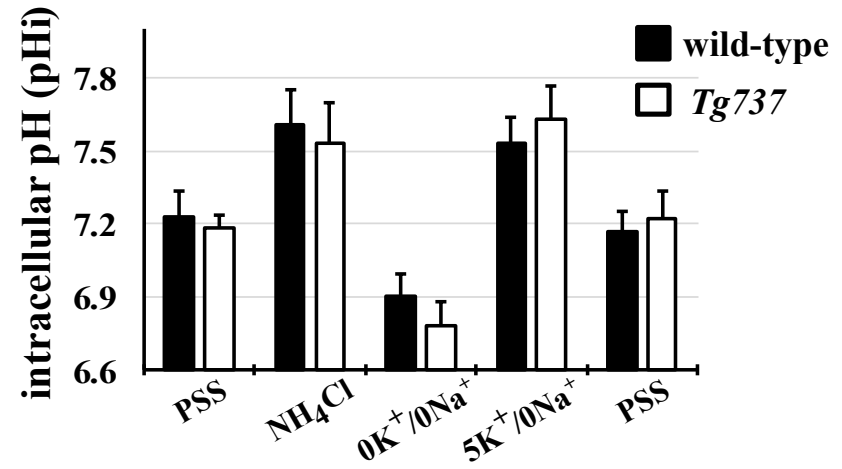

Figure 7. Changes in $\mathrm{pH}_{\mathrm{i}}$ during the $\mathrm{NH}_{4} \mathrm{Cl}$ pre-pulse in wild-type and $\mathrm{Tg} 737$ cells. (a,b) Representative tracings of changes in intracellular $\mathrm{pH}$ when wild-type and $\mathrm{Tg} 737$ cells are exposed to solutions of the $\mathrm{NH}_{4} \mathrm{Cl}$ pre-pulse including the $5 \mathrm{mM} \mathrm{K}^{+}$solution during $\mathrm{pH}_{\mathrm{i}}$ recovery of wild-type and $\mathrm{Tg} 737$ cells. (c) Bar graph shows the summary of $\mathrm{pH}_{\mathrm{i}}$ recovery data from pre-pulse tracings in wild-type and $\mathrm{Tg} 737$ cells. $\mathrm{N}=5$ for wild-type cells and $\mathrm{N}=5$ for $T g 737$ cells with the $5 \mathrm{~K}^{+} / 0 \mathrm{Na}^{+}$solution.

Addition of potassium-containing $5 \mathrm{~K}^{+} / 0 \mathrm{Na}^{+}$solution during $\mathrm{pH}_{\mathrm{i}}$ recovery also influenced MAPK phosphorylation, more specifically p38 phosphorylation (Figure 8). In wild-type cells, p38 phosphorylation coincided with ERK1/2 phosphorylation at acidified $\mathrm{pH}_{\mathrm{i}}$, during the $0 \mathrm{~K}^{+} / 0 \mathrm{Na}^{+}$ step of the $\mathrm{NH}_{4} \mathrm{Cl}$ pre-pulse (10-fold increase in phosphorylation versus control conditions), and p38 phosphorylation persisted through $\mathrm{pH}_{\mathrm{i}}$ recovery using the $5 \mathrm{~K}^{+} / 0 \mathrm{Na}^{+}$solution (5.5-fold increase in phosphorylation versus control conditions). In Tg737 cells, p38 phosphorylation occurred later during $\mathrm{pH}_{\mathrm{i}}$ recovery with the PSS solution (4.0-fold increase in phosphorylation versus control conditions). 
Both ERK1/2 and p38 phosphorylation were absent in $T g 737$ cells as compared to wild-type cells, where significant increases in MAPK phosphorylation occurred after inducing intracellular acidosis.

a) wild-type $\operatorname{Tg} 737$

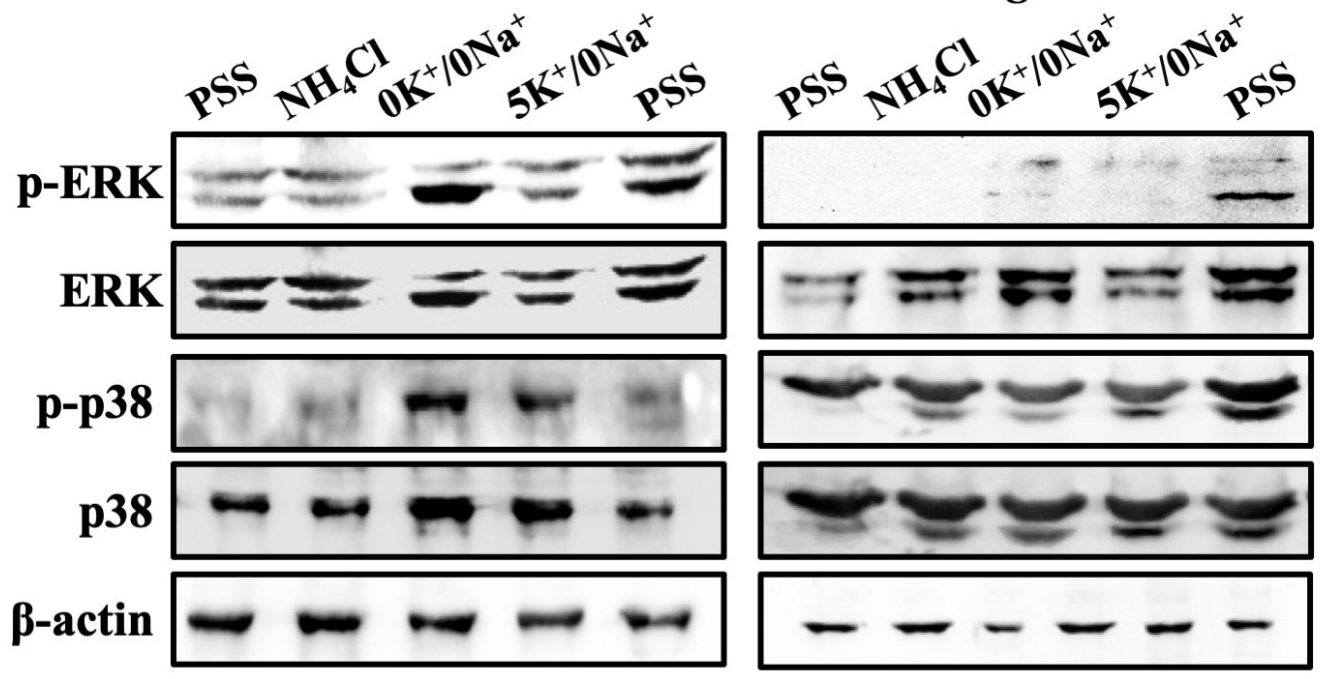

b)

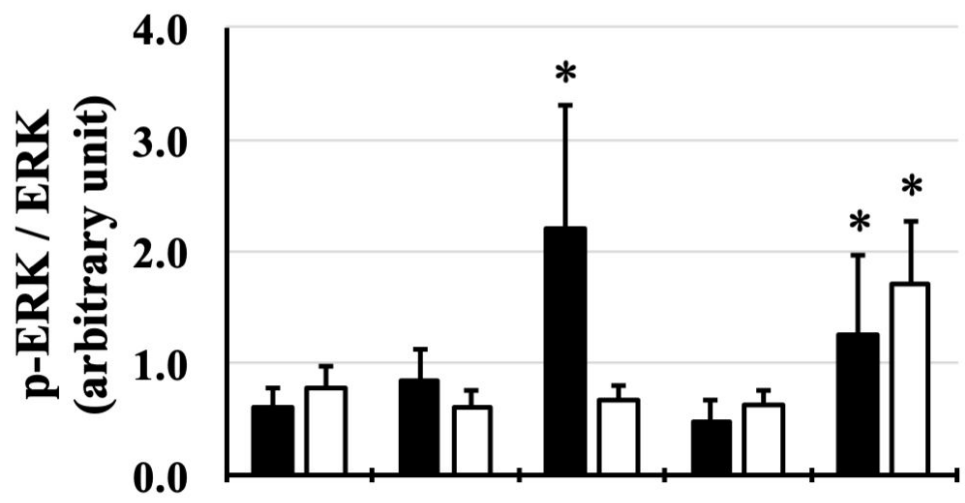

c)

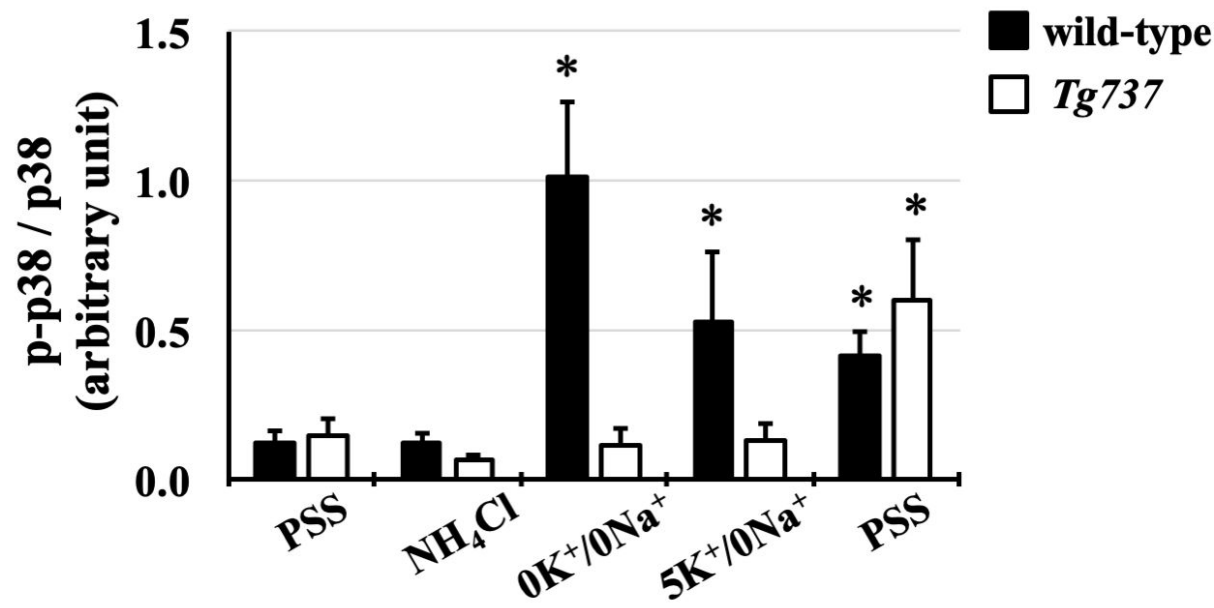

Figure 8. Effect of $\mathrm{K}^{+}$on ERK1/2 and p38 phosphorylation during the $\mathrm{NH}_{4} \mathrm{Cl}$ pre-pulse in wild-type and Tg737 cells. (a) Representative immunoblots show ERK1/2 and p38 phosphorylation in wild-type and $\mathrm{Tg} 737$ cells as they are exposed to different solutions during the $\mathrm{NH}_{4} \mathrm{Cl}$ pre-pulse. (b,c) Bar graphs show mean p-ERK/ERK and p-p38/p38, respectively. * denotes $p<0.05$ as compared to control conditions. For ERK1/2, $N=8$ for wild-type cells and $\mathrm{N}=8$ for Tg737 cells; for $\mathrm{p} 38, \mathrm{~N}=7$ for wild-type cells and $\mathrm{N}=5$ for $\mathrm{Tg} 737$ cells. 


\section{Discussion}

In the present studies, we assessed the role of primary cilia in $\mathrm{pH}$ sensing of vascular endothelial cells. We compared intracellular responses in wild-type and cilia-less $T g 737$ mutant cells against extracellular $\mathrm{pH}$ changes and obtained three main results. First, intracellular $\mathrm{pH}$ homeostasis was not significantly different between the wild-type and Tg737 cells. Second, phosphorylation of two mitogen-activated kinases, $\mathrm{p} 38$ and ERK1/2, were increased by lowering extracellular $\mathrm{pH}$ in both the wild-type and the $T g 737$ cells, but for $T g 737$ cells the same extent of phosphorylation needed a stronger acidic condition. Third, when the cells were exposed to $0 \mathrm{~K}^{+} / 0 \mathrm{Na}^{+}$and $5 \mathrm{~K}^{+} / 0 \mathrm{Na}^{+}$ solutions after the $\mathrm{NH}_{4} \mathrm{Cl}$ solution, the phosphorylation of p38 and ERK1/2 was enhanced only in the wild-type cells.

Wild-type and $T g 737$ cells have similar responses to decreased extracellular $\mathrm{pH}\left(\mathrm{pH}_{\mathrm{o}}\right)$, including decreased intracellular $\mathrm{pH}\left(\mathrm{pH}_{\mathrm{i}}\right)$ relative to drops in $\mathrm{pH}_{\mathrm{o}}$ and acute ERK1/2 and $\mathrm{p} 38$ phosphorylation at $\mathrm{pH}_{\mathrm{o}}<6.0$ (Figures 1-4). Diminished MAPK phosphorylation was observed in $T g 737$ cells compared to wild-type cells at certain $\mathrm{pH}_{\mathrm{o}}$. A significant finding from these experiments was that MAPK phosphorylation in vascular endothelial cells when exposed to low $\mathrm{pH}_{\mathrm{o}}$ may be associated to the cilia or there could be inherited machinery differences between wild-type and $T g 737$ cells in terms of ERK1/2 and p38 phosphorylation.

An acidic environment increased the length of primary cilia in wild-type cells, whereas isolated acidification of intracellular $\mathrm{pH}$ decreased cilia length. The Tg737 cells remained cilia-less under all conditions. Similar to endothelial cells, the NIH3T3 fibroblast cells also presented with longer cilia when challenged with an acidic environment. The physiological significance of this cilia length changes is not clear at present. However, it has been speculated that cilia length could be used as a cellular marker in response to injury or environmental insults [33-35]. SEM micrographs showed no structural defects in the cilia after exposure to acidified media. With the aim of finding any functional effects of acidified media in the cilium, we looked at possible acidic $\mathrm{pH}_{\mathrm{o}}$ induced Hh signaling but found no unexpected activation of $\mathrm{Hh}$.

The next set of experiments were designed to bypass extracellular $\mathrm{pH}$ sensing by lowering intracellular $\mathrm{pH}$ only (Figures 5-8). In terms of $\mathrm{pH}_{\mathrm{i}}$ acidification, $\mathrm{NH}_{4} \mathrm{Cl}$ pre-pulse procedure lowered control and $T g 737$ cell $\mathrm{pH}_{\mathrm{i}}$ in the same manner. Tg737 cells showed no ERK1/2 or p38 phosphorylation in response to decreased intracellular $\mathrm{pH}$, compared to wild-type cells, consistent with a lower $\mathrm{pH}$ requirement as seen in $\mathrm{pH}_{\mathrm{o}}$ induced intracellular acidification. Phosphorylation of $\mathrm{p} 38$ during $\mathrm{K}^{+}$-mediated $\mathrm{pH}_{\mathrm{i}}$ recovery is absent in $T g 737$ cells but this does not produce any differences in $\mathrm{pH}_{\mathrm{i}}$ recovery pattern in comparison to wild-type cells. From our findings we conclude that endothelial cilia are unlikely to serve as the only acid sensing organelle but may be involved in buffering capacity of cytosolic $\mathrm{pH}$ in vascular endothelial cells. The significance in this could mean that ciliopathy (abnormal cilia) may have very little direct role in the physiological acid-base imbalance.

Acid-induced MAPK activation has been observed in the renal epithelial cells [36]. Our studies show that acid activation of MAPK, p38, is relevant in endothelial cells and may be involved in the regulation of acid-mediated transport. Consistent with our observation, Flacke et al. showed that Wistar rat coronary endothelial cells exposed to acidosis ( $\mathrm{pH}$ 6.4) led to a transient activation of $\mathrm{p} 38$ and Akt kinases, which are essential for protection against apoptosis [37].

The importance of $\mathrm{K}^{+}$channels in $\mathrm{pH}_{\mathrm{i}}$ recovery in vascular endothelial cells has been highlighted in this study, with profound increases in intracellular $\mathrm{pH}$ upon addition of $\mathrm{K}^{+}$-containing solution following intracellular acidosis. Our data on $\mathrm{K}^{+}$-dependent $\mathrm{pH}_{\mathrm{i}}$ recovery indicates that $\mathrm{K}^{+}$-transporters are primarily activated by low $\mathrm{pH}_{\mathrm{i}}$, which could include $\mathrm{K}^{+}$-channels, $\mathrm{Na}^{+} / \mathrm{K}^{+}$pumps, and/or $\mathrm{Na}^{+} / \mathrm{K}^{+} / 2 \mathrm{Cl}^{-}$cotransporters. Studies have shown that ATP-sensitive $\mathrm{K}^{+}$channels are activated directly by intracellular but not by extracellular acidosis. This has been established in rat basilar artery where $\mathrm{pH}_{\mathrm{i}}$-acidification mediated dilation was blocked by glibenclamide, an inhibitor of ATP-sensitive potassium channels [38]. Future studies will be needed to determine the precise potassium channel, pump, or transporter responsible for $\mathrm{K}^{+}$-dependent $\mathrm{pH}_{\mathrm{i}}$ recovery in vascular endothelial cells. 
A single, universal $\mathrm{pH} / \mathrm{acid}$ sensor in the cardiovascular and renal systems that regulates MAPK pathways and ion transport has yet to be identified, but there are several possible candidates. These putative $\mathrm{pH}$ sensors expressed by vascular endothelial cells will lie upstream of acid-activated ERK1/2 and p38, and may include epidermal growth factor receptor (EGFR) [4], an acid-sensing ion channel (ASIC) [39], or a G-protein coupled receptor. The GPCR GPR4 is known to be acid-activated $[40,41]$ and regulates potassium-driven transport to maintain $\mathrm{pH}$ [42]. GPR4-null mice have minor defects in renal acid excretion and mild metabolic acidosis. GPR4 deficiency also affects the quality of small blood vessels during angiogenesis [43]. In vascular endothelial cells, acidosis activation of GPR4 stimulates inflammatory responses [43]. With p38 being the notorious inflammatory MAPK [3] and its activation being clear in response to acid $\mathrm{pH}$, GPR4 would be a promising $\mathrm{pH}$ sensor in vascular endothelial cells in the regulation of p38-mediated signaling pathways described here.

Other good candidates for a $\mathrm{pH}$ sensor in vascular endothelial cells are acid-sensing ion channels (ASICs), which are ligand-gated and amiloride-sensitive cation channels activated by extracellular $\mathrm{H}^{+}$[44]. ASICs are members of the degenerin/epithelial sodium channel (DEG/ENaC) superfamily and contain an acidic pocket responsible for acid-dependent gating of sodium and calcium, albeit to a lesser degree. ASICs are expressed in the central and peripheral nervous system, including afferent tissues such as skin, cardiovascular system, muscle, joint, teeth, vestibular, and visceral cells [45].

With the primary cilium being established as a sensor of different mechanical and biochemical cues, we test whether the primary cilium has a role in sensing and transducing $\mathrm{pH}$ changes. We compare acidosis response using vascular endothelial cells as an in vitro model compared to cilia-less $\operatorname{Tg} 737$ cells. Our study on non-motile primary cilia may not be extrapolated to the motile cilia in developing nodes or in the brain ventricles. Nonetheless, our data shows that acid-activation of p38and ERK1/2-mediated signaling pathways regulate ion transport to maintain acid-base homeostasis in endothelia. We showed that $\mathrm{pH}_{\mathrm{i}}$ recovery after an $\mathrm{NH}_{4} \mathrm{Cl}$ pre-pulse in vascular endothelial cells is predominantly a $\mathrm{K}^{+}$-dependent process. We also observed that a more acidic $\mathrm{pH}_{\mathrm{o}}$ was needed to induce MAPK phosphorylation in cilia-less $\mathrm{Tg} 737$ cells compared to wild-type cell. $\mathrm{NH}_{4} \mathrm{Cl}$ pre-pulse is a technique used to create $\mathrm{pH}_{\mathrm{o}}$-independent $\mathrm{pH}_{\mathrm{i}}$ acidification, in this scenario $\mathrm{pH}_{\mathrm{i}}$ recovery was seen to be delayed in $T g 737$ cells. Therefore, we conclude that the primary cilium, a known cardiovascular mechanosensor $[23,46,47]$ and chemoreceptor $[24,48,49]$ is not the sole sensor for acid sensation but does influence the $\mathrm{pH}$ threshold for MAPK kinase phosphorylation. Future studies to examine the identity of the acid sensors distributed in the cilia might be able to detail the nuanced role of primary cilia or $T g 737$ deletion that might affect the buffering capacity of the $T g 737$ mice model.

Supplementary Materials: The following are available online at http://www.mdpi.com/2073-4409/8/7/704/s1, Supplement Movie: 3D reconstruction of z-stack ( $0.25 \mu \mathrm{m}$ slices) from NIH3T3 cells highlighting the cilia (green), Gli (red) and nucleus (blue).Figure S1: NIH3T3 were stained with ciliary marker (acetylated- $\alpha$-tubulin; green), Gli (red) and nucleus marker (DAPI; blue). Figure S2: The lengths of primary cilia from 150 NIH3T3 cells were measured from each preparation ( $\mathrm{N}=3$; each 50 randomly selected cilia). Figure S3: (a) Cilium length of NIH3T3 cells before and after $\mathrm{Hh}$ activation or different acidic $\mathrm{pH}_{\mathrm{o}}$ exposures was averaged. (b) The percentage of cells with cilia is shown. (c) The percentage of cells is shown with Gli localization to the cilia. Figure S4: Electron micrographs of endothelial cells at pH 7.4 (top) and pH 5.5 (bottom). Figure S5: Endothelial cells were stained with ciliary marker (acetylated- $\alpha$-tubulin; green) and nucleus marker (DAPI; blue). Figure S6: The lengths of primary cilia from 150 endothelial cells were measured from each preparation before and after $\mathrm{NH}_{4} \mathrm{Cl}$ pre-pulse in $0 \mathrm{Na}^{+} / \mathrm{K}^{+}$solution $(\mathrm{N}=3$; each 50 randomly selected cilia).

Author Contributions: K.F.A. performed and analyzed data on the endothelial cells and R.T.S. independently confirmed the results and analyses. K.F.A., R.T.S. and S.M.N. contributed in writing the manuscript. All authors read and approved the final manuscript.

Funding: The project was funded in part by Congressionally Directed Medical Research Program PR130153 and the National Institutes of Health HL131577. The funding body had no role in the design of the study and collection, analysis, and interpretation of data and in writing the manuscript.

Acknowledgments: Authors thank Maki Takahashi for her technical support, and the laboratory of Khaled Elsaid for technical assistance with cell maintenance. We thank Juan Codina, Thomas D. DuBose, Jr., and Snezana Petrovic at Wake Forest School of Medicine for their knowledge and technical expertise.

Conflicts of Interest: The authors declare no conflict of interest. 


\section{References}

1. Fisher, K.D.; Codina, J.; Petrovic, S.; DuBose, T.D., Jr. Pyk2 regulates $\mathrm{H}^{+}$-ATPase-mediated proton secretion in the outer medullary collecting duct via an ERK1/2 signaling pathway. Am. J. Physiol. Ren. Physiol. 2012, 303, F1353-F1362. [CrossRef] [PubMed]

2. Li, S.; Sato, S.; Yang, X.; Preisig, P.A.; Alpern, R.J. Pyk2 activation is integral to acid stimulation of sodium/hydrogen exchanger 3. J. Clin. Investig. 2004, 114, 1782-1789. [CrossRef] [PubMed]

3. Johnson, G.L.; Lapadat, R. Mitogen-activated protein kinase pathways mediated by ERK, JNK, and p38 protein kinases. Science 2002, 298, 1911-1912. [CrossRef] [PubMed]

4. Coaxum, S.D.; Blanton, M.G.; Joyner, A.; Akter, T.; Bell, P.D.; Luttrell, L.M.; Raymond, J.R.; Lee, M.H.; Blichmann, P.A.; Garnovskaya, M.N.; et al. Epidermal growth factor-induced proliferation of collecting duct cells from oak ridge polycystic kidney mice involves activation of $\mathrm{Na}^{+} / \mathrm{H}^{+}$exchanger. Am. J. Physiol. Cell Physiol. 2014, 307, C554-C560. [CrossRef] [PubMed]

5. Skelton, L.A.; Boron, W.F. Effect of acute acid-base disturbances on the phosphorylation of phospholipase c-gamma1 and ERK1/2 in the renal proximal tubule. Physiol. Rep. 2015, 3, e12280. [CrossRef]

6. Preisig, P.A. The acid-activated signaling pathway: Starting with pyk2 and ending with increased NHE3 activity. Kidney Int. 2007, 72, 1324-1329. [CrossRef] [PubMed]

7. Zarubin, T.; Han, J. Activation and signaling of the p38 map kinase pathway. Cell Res. 2005, 15, 11-18. [CrossRef]

8. Xue, L.; Lucocq, J.M. Low extracellular pH induces activation of ERK 2, JNK, and p38 in a431 and swiss 3t3 cells. Biochem. Biophys. Res. Commun. 1997, 241, 236-242. [CrossRef]

9. Jin, X.; Mohieldin, A.M.; Muntean, B.S.; Green, J.A.; Shah, J.V.; Mykytyn, K.; Nauli, S.M. Cilioplasm is a cellular compartment for calcium signaling in response to mechanical and chemical stimuli. Cell. Mol. Life Sci. CMLS 2014, 71, 2165-2178. [CrossRef]

10. Kwon, R.Y.; Temiyasathit, S.; Tummala, P.; Quah, C.C.; Jacobs, C.R. Primary cilium-dependent mechanosensing is mediated by adenylyl cyclase 6 and cyclic amp in bone cells. FASEB J. Off. Publ. Fed. Am. Soc. Exp. Biol. 2010, 24, 2859-2868. [CrossRef]

11. Lee, K.L.; Guevarra, M.D.; Nguyen, A.M.; Chua, M.C.; Wang, Y.; Jacobs, C.R. The primary cilium functions as a mechanical and calcium signaling nexus. Cilia 2015, 4, 7. [CrossRef] [PubMed]

12. Masyuk, A.I.; Masyuk, T.V.; Splinter, P.L.; Huang, B.Q.; Stroope, A.J.; LaRusso, N.F. Cholangiocyte cilia detect changes in luminal fluid flow and transmit them into intracellular $\mathrm{Ca}^{2+}$ and camp signaling. Gastroenterology 2006, 131, 911-920. [CrossRef] [PubMed]

13. Yamamoto, K.; Ando, J. New molecular mechanisms for cardiovascular disease:Blood flow sensing mechanism in vascular endothelial cells. J. Pharm. Sci. 2011, 116, 323-331. [CrossRef]

14. Rohatgi, R.; Battini, L.; Kim, P.; Israeli, S.; Wilson, P.D.; Gusella, G.L.; Satlin, L.M. Mechanoregulation of intracellular $\mathrm{Ca}^{2+}$ in human autosomal recessive polycystic kidney disease cyst-lining renal epithelial cells. Am. J. Physiol. Ren. Physiol. 2008, 294, F890-F899. [CrossRef] [PubMed]

15. Nauli, S.M.; Alenghat, F.J.; Luo, Y.; Williams, E.; Vassilev, P.; Li, X.; Elia, A.E.; Lu, W.; Brown, E.M.; Quinn, S.J.; et al. Polycystins 1 and 2 mediate mechanosensation in the primary cilium of kidney cells. Nat. Genet. 2003, 33, 129-137. [CrossRef] [PubMed]

16. Praetorius, H.A.; Spring, K.R. Bending the mdck cell primary cilium increases intracellular calcium. J. Membr. Biol. 2001, 184, 71-79. [CrossRef] [PubMed]

17. Vina, E.; Parisi, V.; Abbate, F.; Cabo, R.; Guerrera, M.C.; Laura, R.; Quiros, L.M.; Perez-Varela, J.C.; Cobo, T.; Germana, A.; et al. Acid-sensing ion channel 2 (asic2) is selectively localized in the cilia of the non-sensory olfactory epithelium of adult zebrafish. Histochem. Cell Biol. 2015, 143, 59-68. [CrossRef]

18. Waldmann, R.; Champigny, G.; Bassilana, F.; Heurteaux, C.; Lazdunski, M. A proton-gated cation channel involved in acid-sensing. Nature 1997, 386, 173-177. [CrossRef]

19. Collier, D.M.; Snyder, P.M. Extracellular protons regulate human enac by modulating $\mathrm{Na}^{+}$self-inhibition. J. Biol. Chem. 2009, 284, 792-798. [CrossRef]

20. Raychowdhury, M.K.; McLaughlin, M.; Ramos, A.J.; Montalbetti, N.; Bouley, R.; Ausiello, D.A.; Cantiello, H.F. Characterization of single channel currents from primary cilia of renal epithelial cells. J. Biol. Chem. USA 2005, 280, 34718-34722. [CrossRef] 
21. Satlin, L.M.; Sheng, S.; Woda, C.B.; Kleyman, T.R. Epithelial Na ${ }^{+}$channels are regulated by flow. Am. J. Physiol. Ren. Physiol. 2001, 280, F1010-F1018. [CrossRef] [PubMed]

22. Banizs, B.; Komlosi, P.; Bevensee, M.O.; Schwiebert, E.M.; Bell, P.D.; Yoder, B.K. Altered pH(i) regulation and $\mathrm{Na}^{+} / \mathrm{HCO}^{-}$transporter activity in choroid plexus of cilia-defective tg737(ORPK) mutant mouse. Am. J. Physiol. Cell Physiol. 2007, 292, C1409-C1416. [CrossRef] [PubMed]

23. Nauli, S.M.; Kawanabe, Y.; Kaminski, J.J.; Pearce, W.J.; Ingber, D.E.; Zhou, J. Endothelial cilia are fluid shear sensors that regulate calcium signaling and nitric oxide production through polycystin-1. Circulation 2008, 117, 1161-1171. [CrossRef] [PubMed]

24. Abdul-Majeed, S.; Nauli, S.M. Dopamine receptor type 5 in the primary cilia has dual chemoand mechano-sensory roles. Hypertension 2011, 58, 325-331. [CrossRef] [PubMed]

25. AbouAlaiwi, W.A.; Takahashi, M.; Mell, B.R.; Jones, T.J.; Ratnam, S.; Kolb, R.J.; Nauli, S.M. Ciliary polycystin-2 is a mechanosensitive calcium channel involved in nitric oxide signaling cascades. Circ. Res. 2009, 104, 860-869. [CrossRef] [PubMed]

26. Yoder, B.K.; Tousson, A.; Millican, L.; Wu, J.H.; Bugg, C.E., Jr.; Schafer, J.A.; Balkovetz, D.F. Polaris, a protein disrupted in ORPK mutant mice, is required for assembly of renal cilium. Am. J. Physiol Ren. Physiol 2002, 282, F541-F552. [CrossRef] [PubMed]

27. Jones, T.J.; Adapala, R.K.; Geldenhuys, W.J.; Bursley, C.; AbouAlaiwi, W.A.; Nauli, S.M.; Thodeti, C.K. Primary cilia regulates the directional migration and barrier integrity of endothelial cells through the modulation of hsp27 dependent actin cytoskeletal organization. J. Cell Physiol. 2012, 227, 70-76. [CrossRef] [PubMed]

28. Aboualaiwi, W.A.; Muntean, B.S.; Ratnam, S.; Joe, B.; Liu, L.; Booth, R.L.; Rodriguez, I.; Herbert, B.S.; Bacallao, R.L.; Fruttiger, M.; et al. Survivin-induced abnormal ploidy contributes to cystic kidney and aneurysm formation. Circulation 2014, 129, 660-672. [CrossRef]

29. AbouAlaiwi, W.A.; Ratnam, S.; Booth, R.L.; Shah, J.V.; Nauli, S.M. Endothelial cells from humans and mice with polycystic kidney disease are characterized by polyploidy and chromosome segregation defects through survivin down-regulation. Hum. Mol. Genet. 2011, 20, 354-367. [CrossRef]

30. Nauli, S.M.; Jin, X.; AbouAlaiwi, W.A.; El-Jouni, W.; Su, X.; Zhou, J. Non-motile primary cilia as fluid shear stress mechanosensors. Methods Enzymol. 2013, 525, 1-20.

31. Dummer, A.; Poelma, C.; DeRuiter, M.C.; Goumans, M.-J.T.H.; Hierck, B.P. Measuring the primary cilium length: Improved method for unbiased high-throughput analysis. Cilia 2016, 5, 7. [CrossRef] [PubMed]

32. Tukachinsky, H.; Lopez, L.V.; Salic, A. A mechanism for vertebrate hedgehog signaling: Recruitment to cilia and dissociation of sufu-gli protein complexes. J. Cell Biol. 2010, 191, 415-428. [CrossRef] [PubMed]

33. Prodromou, N.V.; Thompson, C.L.; Osborn, D.P.; Cogger, K.F.; Ashworth, R.; Knight, M.M.; Beales, P.L.; Chapple, J.P. Heat shock induces rapid resorption of primary cilia. J. Cell Sci. 2012, 125, 4297-4305. [CrossRef] [PubMed]

34. Verghese, E.; Zhuang, J.; Saiti, D.; Ricardo, S.D.; Deane, J.A. In vitro investigation of renal epithelial injury suggests that primary cilium length is regulated by hypoxia-inducible mechanisms. Cell Biol. Int. 2011, 35, 909-913. [CrossRef] [PubMed]

35. Verghese, E.; Weidenfeld, R.; Bertram, J.F.; Ricardo, S.D.; Deane, J.A. Renal cilia display length alterations following tubular injury and are present early in epithelial repair. Nephrol. Dial. Transpl. 2008, 23, 834-841. [CrossRef] [PubMed]

36. Brown, D.; Wagner, C.A. Molecular mechanisms of acid-base sensing by the kidney. J. Am. Soc. Nephrol. 2012, 23, 774-780. [CrossRef] [PubMed]

37. Flacke, J.P.; Kumar, S.; Kostin, S.; Reusch, H.P.; Ladilov, Y. Acidic preconditioning protects endothelial cells against apoptosis through p38- and AKT-dependent bcl-xl overexpression. Apoptosis 2009, 14, 90-96. [CrossRef] [PubMed]

38. Santa, N.; Kitazono, T.; Ago, T.; Ooboshi, H.; Kamouchi, M.; Wakisaka, M.; Ibayashi, S.; Iida, M. ATP-sensitive potassium channels mediate dilatation of basilar artery in response to intracellular acidification in vivo. Stroke 2003, 34, 1276-1280. [CrossRef] [PubMed]

39. Abboud, F.M.; Benson, C.J. Asics and cardiovascular homeostasis. Neuropharmacology 2015, 94, 87-98. [CrossRef] [PubMed]

40. Chen, A.; Dong, L.; Leffler, N.R.; Asch, A.S.; Witte, O.N.; Yang, L.V. Activation of gpr4 by acidosis increases endothelial cell adhesion through the CAMP/EPAC pathway. PLoS ONE 2011, 6, e27586. [CrossRef] 
41. Sun, X.; Yang, L.V.; Tiegs, B.C.; Arend, L.J.; McGraw, D.W.; Penn, R.B.; Petrovic, S. Deletion of the pH sensor gpr4 decreases renal acid excretion. J. Am. Soc. Nephrol. 2010, 21, 1745-1755. [CrossRef] [PubMed]

42. Codina, J.; Opyd, T.S.; Powell, Z.B.; Furdui, C.M.; Petrovic, S.; Penn, R.B.; DuBose, T.D., Jr. pH-dependent regulation of the alpha-subunit of $\mathrm{H}^{+}-\mathrm{K}^{+}$-ATPase (HKalpha2). Am. J. Physiol. Ren. Physiol. 2011, 301, F536-F543. [CrossRef] [PubMed]

43. Dong, L.; Li, Z.; Leffler, N.R.; Asch, A.S.; Chi, J.T.; Yang, L.V. Acidosis activation of the proton-sensing GPR4 receptor stimulates vascular endothelial cell inflammatory responses revealed by transcriptome analysis. PLOS ONE 2013, 8, e61991. [CrossRef] [PubMed]

44. Liu, S.; Cheng, X.Y.; Wang, F.; Liu, C.F. Acid-sensing ion channels: Potential therapeutic targets for neurologic diseases. Transl. Neurodegener. 2015, 4, 10. [CrossRef] [PubMed]

45. Chen, C.C.; Wong, C.W. Neurosensory mechanotransduction through acid-sensing ion channels. J. Cell Mol. Med. 2013, 17, 337-349. [CrossRef] [PubMed]

46. Pedrozo, Z.; Criollo, A.; Battiprolu, P.K.; Morales, C.R.; Contreras-Ferrat, A.; Fernandez, C.; Jiang, N.; Luo, X.; Caplan, M.J.; Somlo, S.; et al. Polycystin-1 is a cardiomyocyte mechanosensor that governs l-type $\mathrm{Ca}^{2+}$ channel protein stability. Circulation 2015, 131, 2131-2142. [CrossRef]

47. Sharif-Naeini, R.; Folgering, J.H.; Bichet, D.; Duprat, F.; Lauritzen, I.; Arhatte, M.; Jodar, M.; Dedman, A.; Chatelain, F.C.; Schulte, U.; et al. Polycystin-1 and -2 dosage regulates pressure sensing. Cell 2009, 139, 587-596. [CrossRef]

48. Kathem, S.H.; Mohieldin, A.M.; Nauli, S.M. The roles of primary cilia in polycystic kidney disease. AIMS Mol. Sci. 2014, 1, 27-46. [CrossRef]

49. Upadhyay, V.S.; Muntean, B.S.; Kathem, S.H.; Hwang, J.J.; Aboualaiwi, W.A.; Nauli, S.M. Roles of dopamine receptor on chemosensory and mechanosensory primary cilia in renal epithelial cells. Front. Physiol. 2014, 5, 72. [CrossRef]

(C) 2019 by the authors. Licensee MDPI, Basel, Switzerland. This article is an open access article distributed under the terms and conditions of the Creative Commons Attribution (CC BY) license (http://creativecommons.org/licenses/by/4.0/). 